\title{
RIOS URBANOS E PAISAGENS MULTIFUNCIONAIS: ESTUDO DE CASO - RIO DONA EUGÊNIA
}

\author{
URBAN RIVERS AND MULTIFUNCTIONAL LANDSCAPES: \\ CASE STUDY - DONA EUGÊNIA RIVER
}

Ianic Bigate Lourenço*

Aline Pires Veról**

Marcelo Gomes Miguez***

Ana Lucia Nogueira de Paiva Britto****

\section{RESUMO}

Observa-se um modelo de urbanização e propostas de intervenção nos cursos de água que ignoram tanto seus valores ambientais, como culturais e sociais, potencializando um dos principais problemas da atualidade nas cidades brasileiras: as cheias urbanas. Este trabalho tem por intuito colaborar com a gestão sustentável das cidades, apresentando soluções paisagísticas, visando à requalificação urbana e ambiental de corpos hídricos a partir do reconhecimento sistêmico das relações físicas, históricas, sociais e ambientais, levando à concepção de soluções multifuncionais

\begin{abstract}
Graduada em Composição Paisagística pela Universidade Federal do Rio de Janeiro (UFRJ). Mestre em Arquitetura Paisagística pelo Programa de Pós-Graduação em Urbanismo da Faculdade de Arquitetura e Urbanismo da Universidade Federal do Rio de Janeiro (PROURB/FAU-UFRJ). Doutoranda no Programa de Engenharia Civil do Instituto Alberto Luiz Coimbra de Pós-Graduação e Pesquisa de Engenharia da Universidade Federal do Rio de Janeiro. (PEC/Coppe/UFRJ). Centro de Tecnologia, bloco I, $2^{\circ}$ andar, sala I-206, Laboratório de Hidráulica Computacional. Avenida Athos da Silveira Ramos, 149, 21941-909, Cidade Universitária, Rio de Janeiro, RJ, Brasil. ianicbigate@gmail.com
\end{abstract}

** Engenheira civil, mestre e doutora em Engenharia Civil pela Universidade Federal do Rio de Janeiro (UFRJ). Professora adjunta da Faculdade de Arquitetura e Urbanismo da Universidade Federal do Rio de Janeiro (FAU/UFRJ). Prédio FAU Reitoria, sala 422. Avenida Pedro Calmon, 550, 21941-901, Cidade Universitária, Rio de Janeiro, RJ, Brasil.

alineverol@fau.ufri.br

*** Engenheiro civil, mestre e doutor em Engenharia Civil pela Universidade Federal do Rio de Janeiro (UFRJ). Professor associado da Escola Politécnica e do Instituto Alberto Luiz Coimbra de Pós-Graduação e Pesquisa de Engenharia da Universidade Federal do Rio de Janeiro (PEC/ Coppe/UFRJ). Centro de Tecnologia, bloco I, $2^{\circ}$ andar, sala I-206, Laboratório de Hidráulica Computacional. Avenida Athos da Silveira Ramos, 149, 21941-909, Cidade Universitária, Rio de Janeiro, RJ, Brasil.

marcelomiguez@poli.ufri.br

**** Geógrafa pela Pontifícia Universidade Católica do Rio de Janeiro (PUC-Rio). Mestre em Planejamento Urbano e Regional pelo Instituto de Pesquisa e Planejamento Urbano e Regional da Universidade Federal do Rio de Janeiro (IPUR-UFRJ). Doutora pelo Institut d'urbanisme de Paris (IUP), Université de Paris XII. Professora associada do Programa de Pós-Graduação em Urbanismo da Faculdade de Arquitetura e Urbanismo da Universidade Federal do Rio de Janeiro (PROURB/ FAU-UFRJ). Prédio FAU Reitoria, sala 521. Avenida Pedro Calmon, 550, 21941-90, Rio de Janeiro, RJ, Brasil. anabrittoster@gmail.com 
- prática essencial frente à escassez de espaços livres que uma cidade de urbanização consolidada normalmente oferece. Diante de sua complexidade, este estudo foi estruturado de modo interdisciplinar, principalmente entre o paisagismo e a engenharia. Esta abordagem permitiu avaliar os impactos da urbanização e, posteriormente, avaliar as soluções paisagísticas propostas, com indicações capazes de representar, hidráulica e hidrologicamente, o comportamento sistêmico da bacia em estudo. $\bigcirc$ trabalho está centrado no rio Dona Eugênia, em Mesquita (RJ), região da Baixada Fluminense, onde é comum o problema de cheias.

Palavras-chave: Rios urbanos. Paisagens multifuncionais. Projeto paisagístico.

\section{ABSTRACT}

It is often observed in the current cities the development of an urbanization model and proposals of intervention on rivers that ignore their environmental, cultural and social values, enhancing one of the main problems of the present days in Brazilian cities: the urban flooding. This work intends to contribute to the sustainable management of cities, presenting landscape solutions, aimed at urban and environmental improvement of water bodies, from the systemic recognition of physical, historical, social and environmental relations, leading to the design of multifunctional solutions, which is an essential practice to face the lack of free spaces that a city of consolidated urbanization usually offers. Considering this complexity, this study was structured in an interdisciplinary basis, mainly between landscaping and engineering. This approach allowed the evaluation of the impacts caused by urbanization and, subsequently, the assessment of the proposed landscape solutions, with indications that are able to represent the hydraulic and hydrological systemic behavior of the study watershed. The work is centered on the Dona Eugênia river in Mesquita, RJ, in theregion of Baixada Fluminense, where the problem of flooding is common.

Keywords: Urban rivers. Multifunctional landscapes. Landscape design.

\section{INTRODUÇÃO}

O processo de intensificação da ocupação urbana, decorrente da necessidade de expansão das cidades, apresenta padrões de uso e ocupação do solo, muitas vezes, desordenados. Nesses casos, é comum observar que muitos rios tiveram seus cursos alterados e áreas de várzeas aterradas, colaborando para o aumento das cheias urbanas, um dos graves problemas associados ao crescimento das cidades. Em grande parte das cidades brasileiras, a ausência de planejamento habitacional levou ao desmatamento e à ocupação irregular de encostas e áreas alagadiças. (MARICATO, 2000; BRANDÃO, 2004; SCHLEE; COELHO NETTO; TÂNGARI, 2006).

Expandindo-se sobre o território dos rios, muitas cidades the voltaram as costas. Como consequência, os rios tornaram-se ocultos na paisagem urbana, considerados meros corredores de drenagem, receptores dos efluentes domésticos e industriais, muitas vezes chamados de valões por sua associação com o transporte de esgoto doméstico.

Diante desse desajuste, cada vez mais evidente em nossas cidades, é necessário trabalhar novos modelos de intervenções, que sejam capazes de mitigar problemas e conflitos em áreas de urbanização consolidada e ordenar o crescimento urbano em locais ainda em desenvolvimento. Devem ser aproveitadas as oportunidades de incorporar áreas vegetadas, de preferência arborizadas (de todos os tipos e tamanhos), e desconectar solos impermeabilizados. Inúmeras tipologias têm sido desenvolvidas para viabilizar tais estratégias, como alagados construídos, corredores verdes, jardins de chuva, canteiros pluviais, tetos, muros verdes. (CORMIER; PELLEGRINO, 2008). 
Com o objetivo de contribuir para a reformulação de nossas cidades, este trabalho procurará apresentar possíveis soluções paisagísticas para requalificação urbana e ambiental de corpos hídricos em bacias densamente urbanizadas, prevendo diferentes relações sistêmicas: históricas, sociais e ambientais, inclusive as que envolvem dimensões subjetivas, como a interação afetiva entre ambiente natural e humano. $O$ planejamento da paisagem deve ser fundamentado em conhecimentos de ciências físicas, biológicas e sociais, e utilizar as técnicas e a criatividade do paisagismo (MCHARG, 1969; LYNCH, 1984; FABOS, 1985; STEINER, 1991; NASSAUER, 1997; SPIRN, 2002, JOHNSON; HILL, 2002). Isso será possível por meio de abordagem interdisciplinar, integrando soluções da engenharia e do paisagismo visando ao redesenho da paisagem para que esta tenha eficiência urbana, ambiental, econômica e social.

Os lugares possuem características únicas - compostas pela combinação de seus habitantes, sua história, sua cultura e seus atributos naturais - que devem ser reconhecidas como base para projetos urbanos sustentáveis. Dessa forma, poderão ser aceitas e contribuir para que os valores culturais sejam compatibilizados com as suas bases ecológicas. Valorizar a história e as vivências do lugar, por meio de atividades e iniciativas que perpetuem e multipliquem seu conhecimento, é uma estratégia que usa as práticas culturais e as artes para celebrar o sentido de lugar. (NEWMAN; JENNINGS, 2008).

É preciso evidenciar a complexidade de uma proposta como essa, devido à necessidade de articulá-la a ações integradas de políticas públicas que valorizem a gestão sustentável das cidades. $\bigcirc$ foco principal deste trabalho será apresentar uma proposta de intervenção que vise compatibilizar urbanização com sustentabilidade. Espera-se a concepção de possíveis soluções paisagísticas sustentáveis, embasadas na requalificação fluvial de rios urbanos e em um novo sistema de espaços livres multifuncionais.

A abordagem da requalificação fluvial inclui a procura por um balanço compatível entre as necessidades do homem e a dinâmica da natureza, oferecendo oportunidades efetivas e sustentáveis para enfrentar o problema do risco hidráulico. (CIRF, 2006). Os espaços multifuncionais permitem que os poucos espaços livres que restam em cidades de urbanização já consolidada associem funções hidráulicas a funções social, ambiental e econômica.

Spirn (1995), em O jardim de granito: a natureza no desenho da cidade, critica projetos urbanos superficiais criados apenas para embelezar a natureza da cidade. Para a autora, são necessárias mudanças radicais, que busquem reconhecer e apontar uma série de danos, decorrentes de intervenções sobre rios urbanos, que não respeitam a natureza e que têm sido adotados mais como embelezamento superficial do que como parte de uma força essencial que permeia a cidade. A autora descreve mais opções para o tratamento de rios urbanos, em relação às usualmente consideradas pelos projetos de engenharia convencional: "A chave para se alcançar soluções eficientes, efetivas e econômicas é uma compreensão das várias maneiras como as águas se movem através da cidade." (SPIRN, 1995, p. 161). Ela reconhece que cada espaço deve funcionar não apenas como um pequeno sistema local, mas como parte de um sistema maior e mais amplo de uso do solo e ambientes. Cada espaço não deve ser pensado exclusiva- 
mente para um fim; deve ser extremamente valorizado. Parques e espaços livres devem servir a muitos propósitos: recuperação de resíduos urbanos, preservação de recursos minerais, armazenamento das águas de cheias, estabilização de encostas instáveis e áreas florestadas. Os espaços livres da cidade são partes de um sistema multifacetado e interligado da mesma. Para McHarg (1969), é possível conciliar as aspirações da sociedade tecnológica com a preservação dos processos ecológicos existentes, peculiares de um território. Essa preservação implica não só na obtenção de uma qualidade de vida, no mínimo satisfatória, como também na valorização das próprias características do meio físico. Demonstrou que ao planejar - considerando as potencialidades e restrições oferecidas pelo ambiente físico e cultural - benefícios sociais também são obtidos, superando as expectativas. Laurie (1975 apud HERZOG, 2009, p. 28), no livro Introduction to landscape architecture, argumentou sobre a essência do que define como planejamento da paisagem:

[...] a habilidade de tomar decisões baseadas nos critérios de fragilidade e valores que dependem da compreensão do ambiente e dos processos naturais e relações ecológicas básicas que ocorrem. É necessário encontrar uma maneira de avaliar as variáveis do sistema natural para que possam se tornar fatores determinantes poderosos e estratégicos para definir políticas de seu uso e de sua forma na tarefa de planejamento de projeto.

Procura-se, assim, demonstrar como novas propostas de soluções paisagísticas para a requalificação de rios urbanos, com foco no projeto e baseadas numa visão sistêmica, podem gerar melhoria da qualidade ambiental, urbana e da qualidade de vida da população.

Este trabalho está centrado no estudo de caso do rio Dona Eugênia, no município de Mesquita (RJ). Essa escolha se deu por ser um rio localizado na Baixada Fluminense, região metropolitana do Rio de Janeiro que apresenta características de crescimento urbano desordenado, sendo constantemente abalada por eventos de cheias urbanas. Tais características impulsionaram o desenvolvimento deste trabalho.

\section{POR UMA NOVA PAISAGEM}

Rios podem ser considerados a síntese dos territórios a eles conectados (CIRF, 2006). Devem ser reconhecidos como estruturas ambientais extremamente importantes na construção da paisagem, pois representam valores ambientais e revelam valores culturais e estéticos, porém esta visão tem sido constantemente desconsiderada.

Mann (1973) observa que os corpos hídricos das cidades têm sido os recursos naturais mais usados e abusados do planeta. Sem dúvida, é impossível viabilizar áreas para expansão urbana e ações relacionadas ao desenvolvimento econômico sem que ocorram prejuízos ambientais, como alteração da dinâmica hidrológica das bacias hidrográficas. No entanto, é possível avaliar previamente as fragilidades naturais, 
as alterações introduzidas no meio e prever áreas ecologicamente mais valiosas a serem preservadas.

Nas grandes cidades ocorre, em geral, a falta de visibilidade dos cursos d'água, com pouca ou nenhuma convivência da mesma com ecossistemas naturais. A artificialização de áreas de lazer (shopping centers, condomínios, playgrounds, praças), onde se concentra a maior parte das atividades de convívio social, é um dos fatores que têm levado à alienação e não compreensão do papel dos ecossistemas e do sistema hídrico para a sustentabilidade das cidades e do planeta. (COSTA, 2006).

Para viabilizar a expansão urbana, a especialização técnica levou a obras de engenharia pesada para resolver problemas causados pela ocupação de áreas inadequadas, com a supressão de ecossistemas naturais e de vegetação arbórea, aterros de áreas úmidas, drenagem artificial, retificação e canalização de rios e córregos. Em geral, as soluções têm sido pontuais, com prioridade para a circulação de veículos, sem focar repercussões em longo prazo. (PELLEGRINO et al., 2006). Contudo, alcançar uma situação de drenagem urbana sustentável implica em que sistemas de drenagem urbana tenham que ser planejados de forma integrada com o crescimento urbano, com as soluções de drenagem, devendo ser integradas com a paisagem urbana (MIGUEZ et al., 2007).

É necessária a revisão dos aspectos atuais de desenho urbano e de uso e ocupação do solo. É preciso redescobrir a essência dos lugares em que se vive, através de visões que abranjam conceitos interdisciplinares, entendidos durante muito tempo como dimensões separadas: cidade $x$ natureza. É necessário considerar todas as variáveis possíveis a serem abarcadas em um projeto para que seja ecologicamente responsável, quando o homem deixa de ser um estranho ao meio ambiente, passando a fazer parte dele. Neste trabalho entende-se o projeto paisagístico não apenas como intervenções pontuais ao longo do curso do rio, mas como um projeto que prevê a contextualização do rio da cidade, tomando sua bacia hidrográfica como referência. Nesse sentido, a requalificação fluvial trabalhada a partir de uma paisagem multifuncional apresenta-se como forma de intervenção que não se limita a solucionar problemas ocasionados por cheias urbanas, pois proporciona inúmeros benefícios à área urbana, à população que dela se utiliza e ao sistema fluvial. São apresentadas as figuras 1 e 2, para efeito comparativo, sendo possível visualizar que, por meio de medidas de planejamento e projeto da paisagem, situações de inundações urbanas recorrentes podem ser mitigadas.

A implementação de um projeto como esse é capaz de trazer reais melhorias para a qualidade de vida da população e do meio ambiente. Tomando como referência a bacia escolhida para este estudo, a figura 1 apresenta a mancha atual de alagamento para a Bacia do rio Dona Eugênia. Ela aponta a mancha de alagamento para chuva de recorrência de vinte e cinco anos - normalmente adotada para o planejamento e gestão das águas no Brasil, atendendo à recomendação do Ministério das Cidades. Nela pode-se reconhecer um problema crônico na rede de microdrenagem, pela sua ineficiência e, por vezes, pela sua inexistência.

As redes de macrodrenagem também apresentam problemas graves devido ao uso e ocupação do solo inadequados e às intervenções de drenagem urbana, que seguem 
padrões tradicionais. Já a figura 2 apresenta o mapa de alagamento para a situação de Requalificação Fluvial + Drenagem Urbana Sustentável. Segundo Veról (2013), uma análise técnica das medidas adotadas aponta que esse cenário apresentou resultados positivos, eliminando vários pontos de alagamento e diminuindo a lâmina d'água em outros. Em linhas gerais, a proposta conceitual da conjugação da requalificação fluvial com a drenagem urbana sustentável mostrou-se eficaz na redução das manchas de alagamento e no resgate de características do sistema fluvial, com benefícios para o próprio rio e para a cidade.

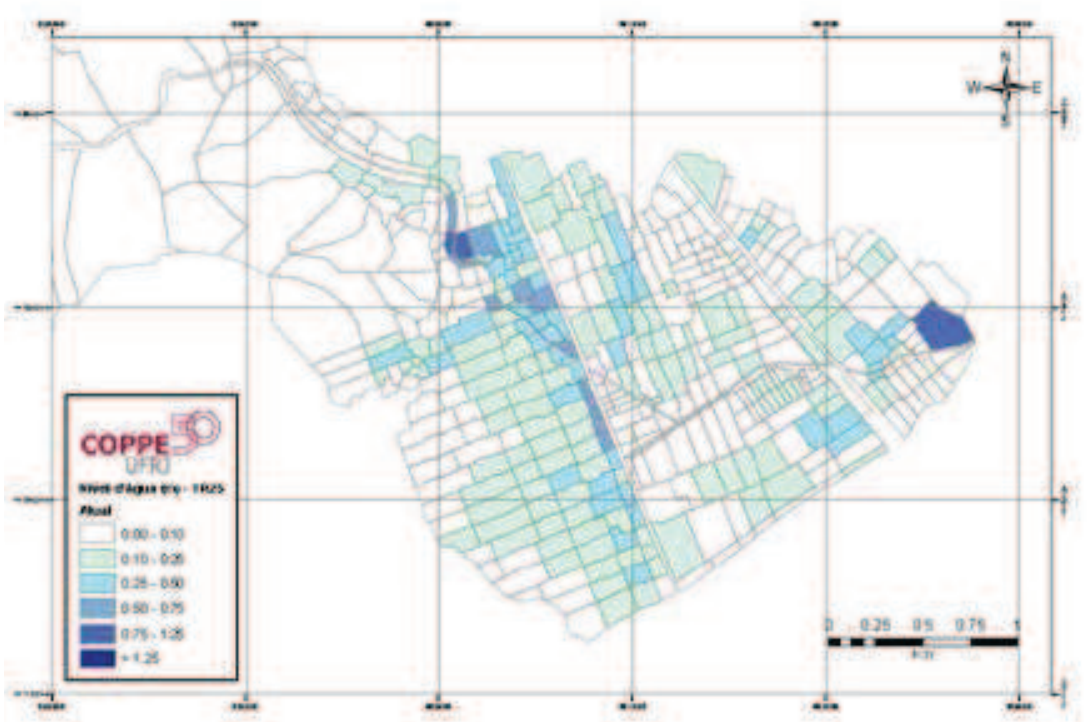

Figura 1 Mancha de Alagamento (TR 25 anos). Fonte: Veról (2013, p. 247).

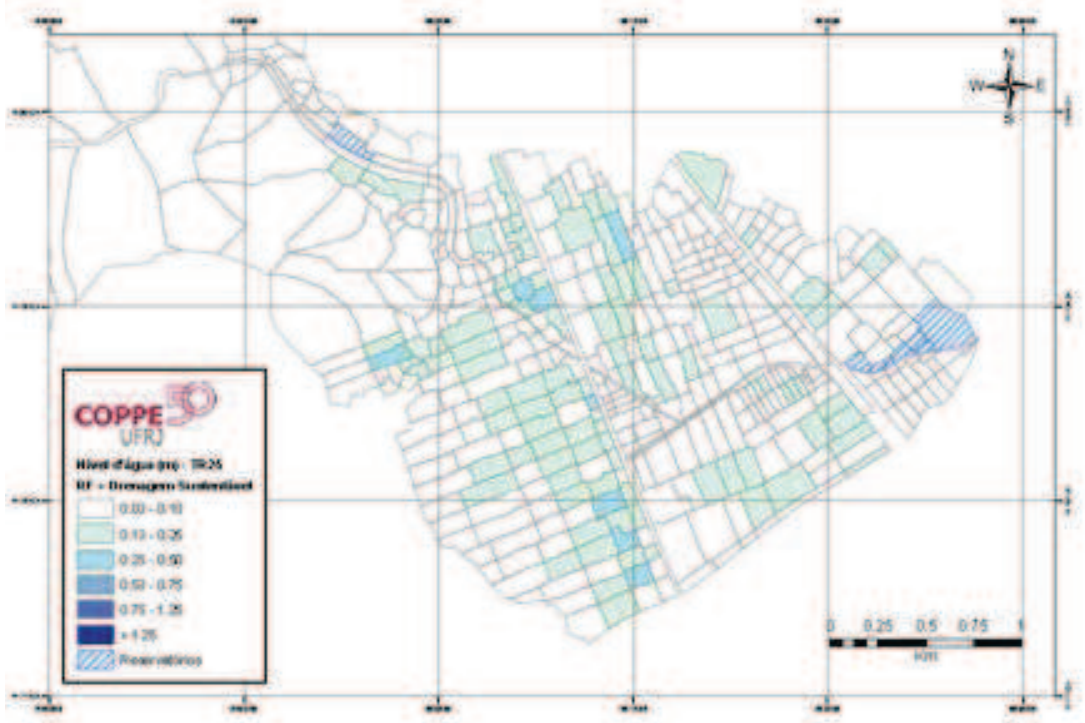

Figura 2 Mancha de Alagamento - Requalificação Fluvial + Drenagem Sustentável (TR 25 anos). Fonte: Veról (2013, p. 270). 
Para alcançar esse resultado, a pesquisa foi realizada de forma a, primeiramente, identificar as relações sistêmicas que se estabelecem entre o ambiente natural e os sistemas urbanos, incluindo os aspectos social e econômico, prevendo diferentes escalas de observação para caracterizar as questões que permeiam a recuperação de um corpo hídrico. Posteriormente, com base no diagnóstico, foram apontadas as diretrizes e ações projetuais de acordo com os conceitos trabalhados. Diante da complexidade do tema e da necessidade de interação entre diferentes campos do conhecimento, este trabalho teve como base a interdisciplinaridade como forma de alcançar resultado factível.

\section{APRESENTAÇÃO DO ESTUDO DE CASO}

A sub-bacia do rio Dona Eugênia está situada na Bacia dos rios Iguaçu-Sarapuí (figura 3). Segundo o Plano Diretor de Recursos Hídricos da Bacia dos rios Iguaçu-Sarapuí (1999), a mesma faz parte do complexo de bacias hidrográficas que deságuam na Baía de Guanabara, na cidade do Rio de Janeiro (RJ).
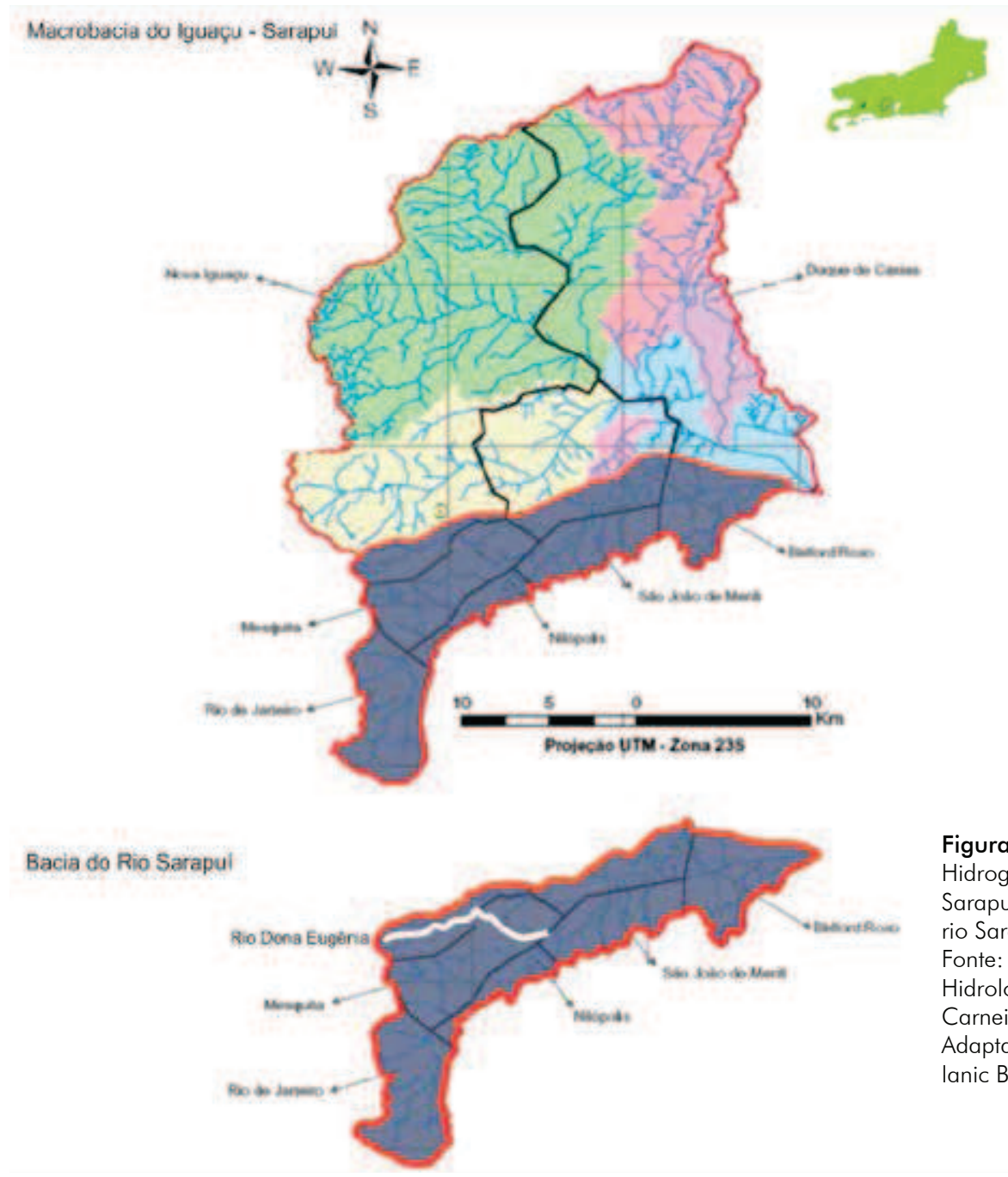

Figura 3 Macrobacia Hidrográfica lguaçuSarapuí e Bacia do rio Sarapuí. Fonte: Laboratório de Hidrologia COPPE. Carneiro (2008). Adaptada por lanic Bigate. 
A conjugação dos fatores naturais e de ocupação humana gerou crescimento exponencial no problema das cheias urbanas na Bacia do rio Sarapuí, formando um cenário de difícil reversão, onde a ocupação das encostas, a ocupação marginal, os aterros, a impermeabilização do solo, a canalização e o grande volume de resíduos sólidos são os principais impactos à cobertura vegetal e aos corpos hídricos da bacia. A situação da sub-bacia do rio Dona Eugênia não difere dessas condições.

\section{Sub-bacia do rio Dona Eugênia}

A sub-bacia do rio Dona Eugênia encontra-se, em sua maior parte, no município de Mesquita, na Baixada Fluminense. Segundo dados do Instituto Brasileiro de Geografia e Estatística (IBGE, 2010), seu território tem área de 39.062 km² e a população estimada é de 168.376 mil habitantes. O rio nasce em Área de Proteção Ambiental (APA) e atravessa praticamente toda a cidade, com aproximadamente seis quilômetros de extensão em área urbana.
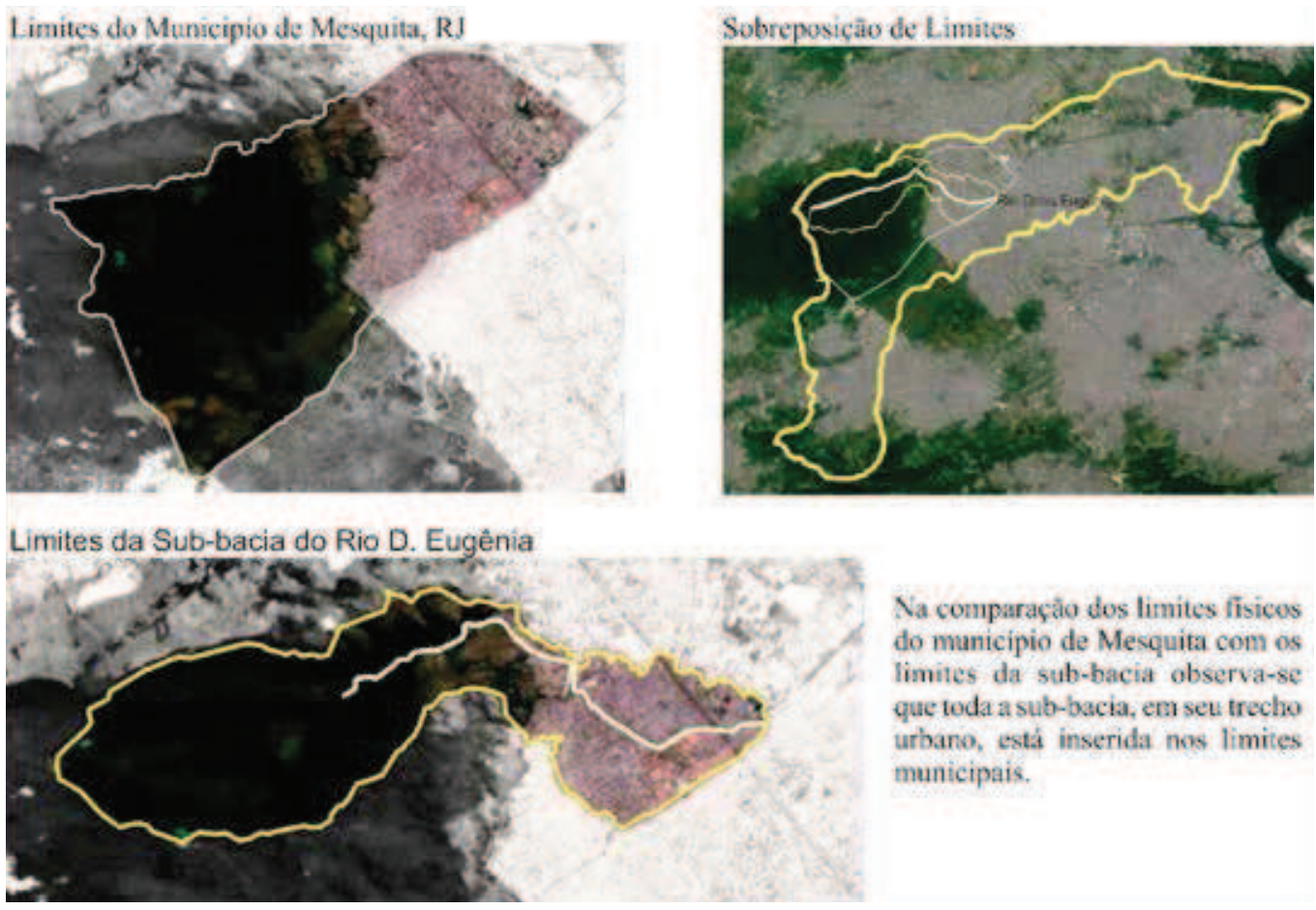

Na comparaçầo dos limites físices do municipio de Mesquita com os limites da sub-bacia observa-se que toda a sub-bacia, em set trecho urbano, está inserida nos limites municipais.

Figura 4 Limites: município, Bacia rio Dona Eugênia e sobreposição de limites. Fonte: Lourenço (2013, p. 82).

\section{Problematização resumida da Sub-bacia do rio Dona Eugênia}

Foram observados todos os aspectos que compõem as dinâmicas atuais dessa paisagem, apresentados a seguir, de forma resumida, para posterior utilização na construção de soluções que configuraram nova paisagem para a sub-bacia. 


\section{Problemas e Conflitos}

Toda bacia sofre impactos da urbanização, que geram prejuízos diversos em função dos aspectos do crescimento. Não é diferente na bacia em estudo, na qual se observa (figura 5) que a ação antrópica, que promoveu desmatamento, polvição, assoreamento dos rios e ocupação marginal, gerou impactos na paisagem natural. Esses impactos são sentidos, principalmente, na recorrência dos eventos de alagamentos.

\section{Problematização}
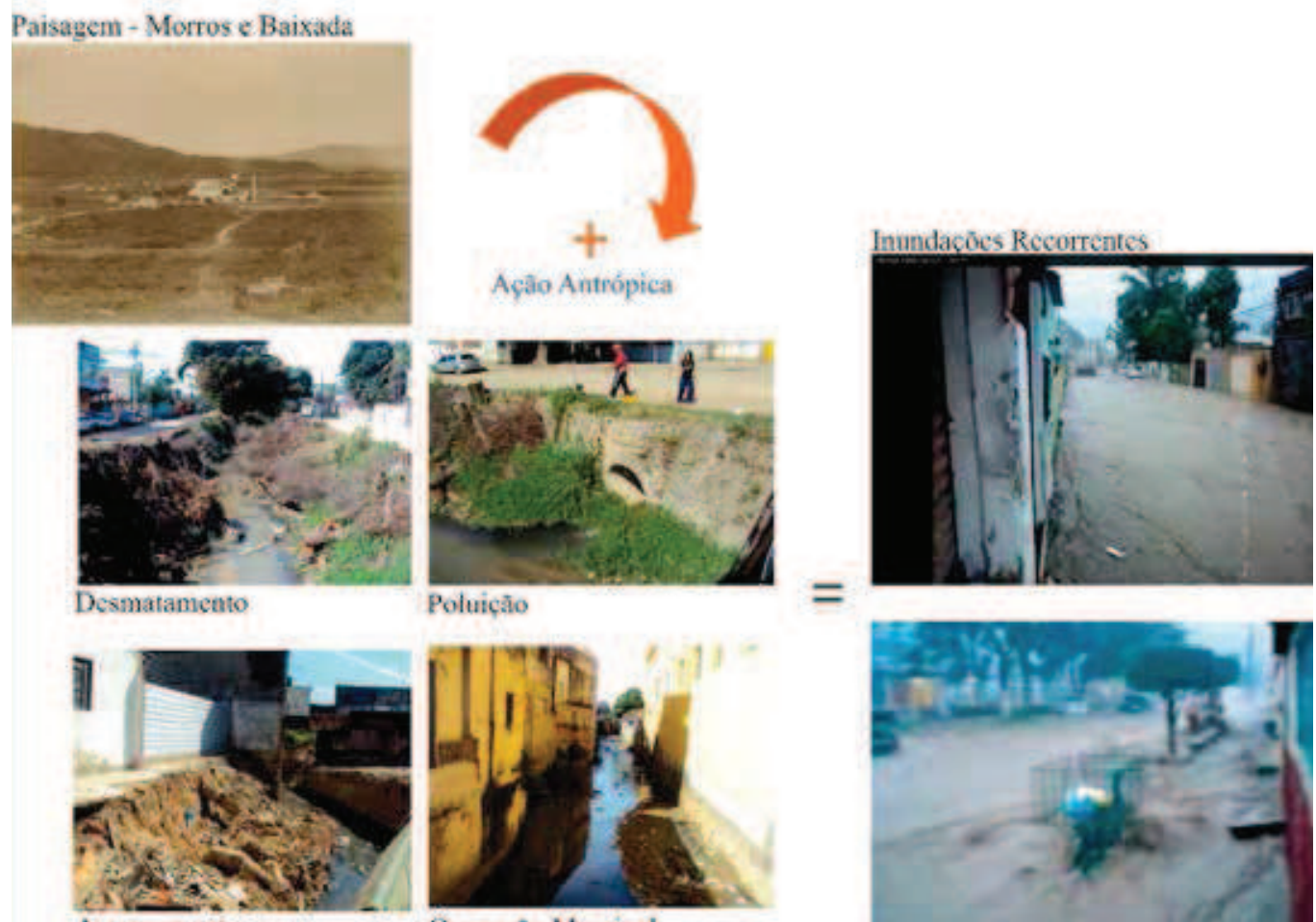

Poluị̧̣åo

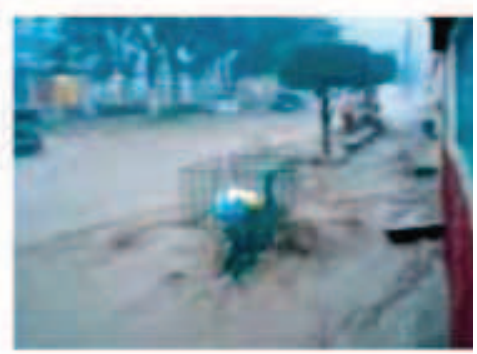

Figura 5 Síntese Problemas e Conflitos na sub-bacia do rio Dona Eugênia.

Fonte: Lourenço (2013). Adaptada por lanic Bigate Lourenço.

\section{Potencialidades}

Apesar dos impactos gerados pela urbanização, a bacia ainda apresenta características naturais capazes de promover valorização ambiental e urbana por meio da incorporação de tais aspectos nas propostas de requalificação. A seguir (figura 6), observam-se as principais potencialidades da bacia, que, além de seus atributos perceptivos, apresenta outros potenciais ambientais, como extensa APA. Existe outro importante aspecto: o tamanho reduzido do rio, que, pelo fato de sua extensão em área urbana estar nos limites de um único município, aponta que o rebatimento de políticas públicas pode ser facilitado. 


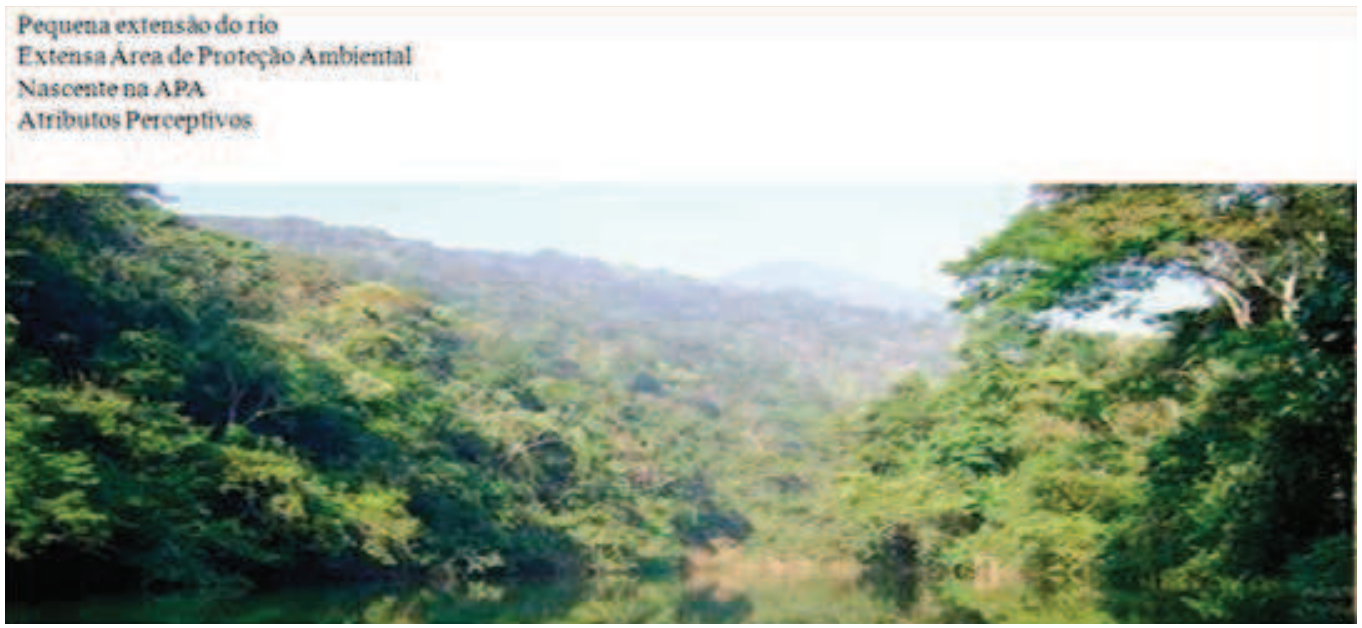

Figura 6 Potencialidades - Vista da barragem.

Disponível em: <http://gehnat-ong.blogspot.com.br/2008/07/>. Acesso em: jun. 2013.

Considerando a problematização da bacia para proposições de mitigação dos problemas e potencialização de qualidades, serão elencadas (tabela l) as situações-tipo principais, caracterizadas pelos principais problemas e conflitos. Posteriormente, serão estipuladas as diretrizes projetuais que visam nortear as ações projetuais para, por fim, apresentar soluções para as situações-tipo.

Tabela I Diretrizes

\begin{tabular}{l|l|l}
\hline \multicolumn{1}{c|}{ SITUAÇÕES TIPO } & \multicolumn{1}{c|}{$\begin{array}{c}\text { DIRETRIZES } \\
\text { PROJETUAIS }\end{array}$} & \multicolumn{1}{c}{ AÇÕES PROJETUAIS } \\
\hline $\begin{array}{l}\text { Pressão do crescimento } \\
\text { urbano para APAs. }\end{array}$ & $\begin{array}{l}\text { Contenção do crescimento } \\
\text { urbano; preservação da } \\
\text { nascente; redefinição da APA } \\
\text { para reserva biológica. }\end{array}$ & $\begin{array}{l}\text { Parque Urbano de Borda. } \\
\text { Revegetação. }\end{array}$ \\
\hline $\begin{array}{l}\text { Ausência de conexão entre } \\
\text { meio urbano } \\
\text { e ecológico. }\end{array}$ & $\begin{array}{l}\text { Constituição de um Sistema } \\
\text { de Espaços Livres - novas } \\
\text { conexões que visam maior } \\
\text { interação do meio natural e } \\
\text { urbano. }\end{array}$ & $\begin{array}{l}\text { Vois grandes PULMÕES } \\
\text { interconectados por paisagens } \\
\text { multifuncionais - corredores } \\
\text { ecológicos, parques, APAs e e } \\
\text { reconstituição e fomentação da } \\
\text { vegetação. }\end{array}$ \\
\hline
\end{tabular}

APA - ÁREA DE PROTEÇÃO AMBIENTAL. Unidade de conservação destinada a proteger e conservar a qualidade ambiental e os sistemas naturais nela existentes para a melhoria da qualidade de vida da população local e proteção dos ecossistemas regionais. 


\begin{tabular}{|c|c|c|}
\hline $\begin{array}{l}\text { Escassez de vegetação } \\
\text { urbana. }\end{array}$ & $\begin{array}{l}\text { Fomentação da vegetação } \\
\text { marginal e áreas livres } \\
\text { públicas e em vias. }\end{array}$ & $\begin{array}{l}\text { Criação de corredores vegetais } \\
\text { com espécies visualmente } \\
\text { atrativas, de rápido crescimento, } \\
\text { e espécies específicas para área } \\
\text { marginal. }\end{array}$ \\
\hline $\begin{array}{l}\text { Desvalorização das } \\
\text { margens do rio. }\end{array}$ & Revitalização marginal. & $\begin{array}{l}\text { Revegetação. } \\
\text { Áreas de lazer e recreação. } \\
\text { Utilização na mobilidade - } \\
\text { ciclovias e passeios. } \\
\text { Transformação das vias marginais } \\
\text { em Traffic Calming², com mão } \\
\text { única e de velocidade reduzida. }\end{array}$ \\
\hline $\begin{array}{l}\text { Segregação espacial - } \\
\text { linha férrea e } \\
\text { faixa não edificante } \\
\text { da Light }^{3} \text {. }\end{array}$ & $\begin{array}{l}\text { Criar conexões visuais } \\
\text { e conexões urbanas e } \\
\text { ecológicas. }\end{array}$ & $\begin{array}{l}\text { Substituição do muro por gradil } \\
\text { quando possível. } \\
\text { Faixa não edificante da Light } \\
\text { como parte integrante do sistema } \\
\text { de espaços livres, como área } \\
\text { de lazer e tratamento de águas } \\
\text { pluviais urbanas. }\end{array}$ \\
\hline $\begin{array}{l}\text { Ocupação de áreas } \\
\text { marginais. }\end{array}$ & $\begin{array}{l}\text { Novas formas de } \\
\text { assentamento urbano e } \\
\text { padrões construtivos que } \\
\text { respeitem o ciclo das } \\
\text { águas. }\end{array}$ & $\begin{array}{l}\text { Relocação das habitações } \\
\text { para o mesmo local, ou local } \\
\text { próximo, sob novos modelos } \\
\text { de assentamento e padrões } \\
\text { construtivos. }\end{array}$ \\
\hline $\begin{array}{l}\text { Expansão urbana em áreas } \\
\text { alagáveis. }\end{array}$ & $\begin{array}{l}\text { Preservação de áreas } \\
\text { alagáveis. }\end{array}$ & $\begin{array}{l}\text { Criação de um parque alagado - } \\
\text { Pulmão verde. } \\
\text { Estabelecimento de } \\
\text { assentamentos formais em locais } \\
\text { de expansão, respeitando os } \\
\text { limites do parque ambiental e } \\
\text { seguindo padrões de técnicas } \\
\text { sustentáveis de projeto urbano. }\end{array}$ \\
\hline
\end{tabular}

2 TRAFFIC CALMING - finalidade de reduzir a velocidade dos veículos e criar ambiente que induza à direção segura.

3 LIGHT - Empresa distribuidora de energia elétrica da cidade do Rio de Janeiro. A faixa não edificante da Light compreende faixas de linha de transmissão, que se caracterizam como locais com restrições, com limitações no tocante à implementação de uso e ocupação que configuram violação dos padrões de segurança estabelecidos nas normas técnicas e procedimentos das concessionárias de energia. 


\begin{tabular}{l|l|l}
\hline $\begin{array}{l}\text { Canalização, estreitamento } \\
\text { e impermeabilização } \\
\text { do rio. }\end{array}$ & $\begin{array}{l}\text { Supressão da canalização } \\
\text { e abertura do leito do rio } \\
\text { quando possível. }\end{array}$ & $\begin{array}{l}\text { Leito e margens do rio mais } \\
\text { naturais e permeáveis; } \\
\text { revegetação marginal; sistema } \\
\text { de espaços livres para aberturas } \\
\text { do leito. }\end{array}$ \\
\hline $\begin{array}{l}\text { Despejo das águas } \\
\text { urbanas no rio. }\end{array}$ & $\begin{array}{l}\text { Evitar o despejo direto no rio } \\
\text { através de medidas estruturais } \\
\text { e não estruturais. }\end{array}$ & $\begin{array}{l}\text { Utilização de técnicas } \\
\text { sustentáveis de projeto } \\
\text { urbano: infraestrutura verde e } \\
\text { construção de canal coletor ao } \\
\text { longo do rio, evitando despejo } \\
\text { das águas pluviais e do esgoto } \\
\text { in natura. }\end{array}$ \\
\hline $\begin{array}{l}\text { Deposição de lixo no } \\
\text { leito do rio. }\end{array}$ & $\begin{array}{l}\text { Educação ambiental. } \\
\text { Melhoria no serviço de coleta. }\end{array}$ & $\begin{array}{l}\text { Conscientização por meio da } \\
\text { aproximação da população } \\
\text { com as áreas revitalizadas. }\end{array}$ \\
\hline $\begin{array}{l}\text { Inundações e } \\
\text { enchentes. }\end{array}$ & $\begin{array}{l}\text { Associação de todas as } \\
\text { demais diretrizes projetuais. } \\
\text { espaços livres como gerador } \\
\text { de emprego e renda para a } \\
\text { população local. }\end{array}$ & $\begin{array}{l}\text { Asodução e venda de espécies } \\
\text { vegetais locais; concentração } \\
\text { de atividades rentáveis: } \\
\text { quiosques, novos centros } \\
\text { comerciais. }\end{array}$ \\
\hline
\end{tabular}

Fonte: Lourenço (2013, p. 122).

\section{O Projeto Paisagístico}

\section{Reestruturação Ecológica e Urbana}

Redefinição das Relações: Sociedade - Natureza

projeto paisagístico proposto, conforme as figuras 7 e 8 , tem como elemento reestruturador da bacia o seu sistema ecológico: aspectos hídricos e vegetação. A partir desses elementos foram adotados novos sistemas de infraestrutura e tipologias construtivas que asseguram a redefinição das relações entre sociedade e natureza, tornando-as mais harmônicas e mitigando ações antrópicas que foram impactantes na bacia.

Levando em consideração que se trata de uma bacia de urbanização consolidada, foram trabalhados os espaços com características multifuncionais, pois não é simples tomar aspectos ecológicos como estruturadores de novas paisagens, capazes de promover as requalificações urbana e ambiental, uma vez que bacias nessa condição de desenvolvimento urbano oferecem poucas condições e poucos espaços ainda livres para serem trabalhados de forma sistêmica. 
Sistema Ecológico: Água e Vegetação

Novo elemento estruturador

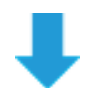

Sistemas: Infraestrutura e

Tipos Construtivos

- Viária

- Saneamento Básico

- Aspectos Econômicos

- Novas formas de ocupação que se associem

ao sistema ecológico

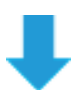

- Atividades Ambientais

- Atividades de lazer e recreação

- Atividades Econômicas

- Atividades Esportivas
Figura 7 Reestruturação ecológica e urbana redefinição das relações sociais e ambientais. Fonte: Lourenço $(2013$, p. 127).

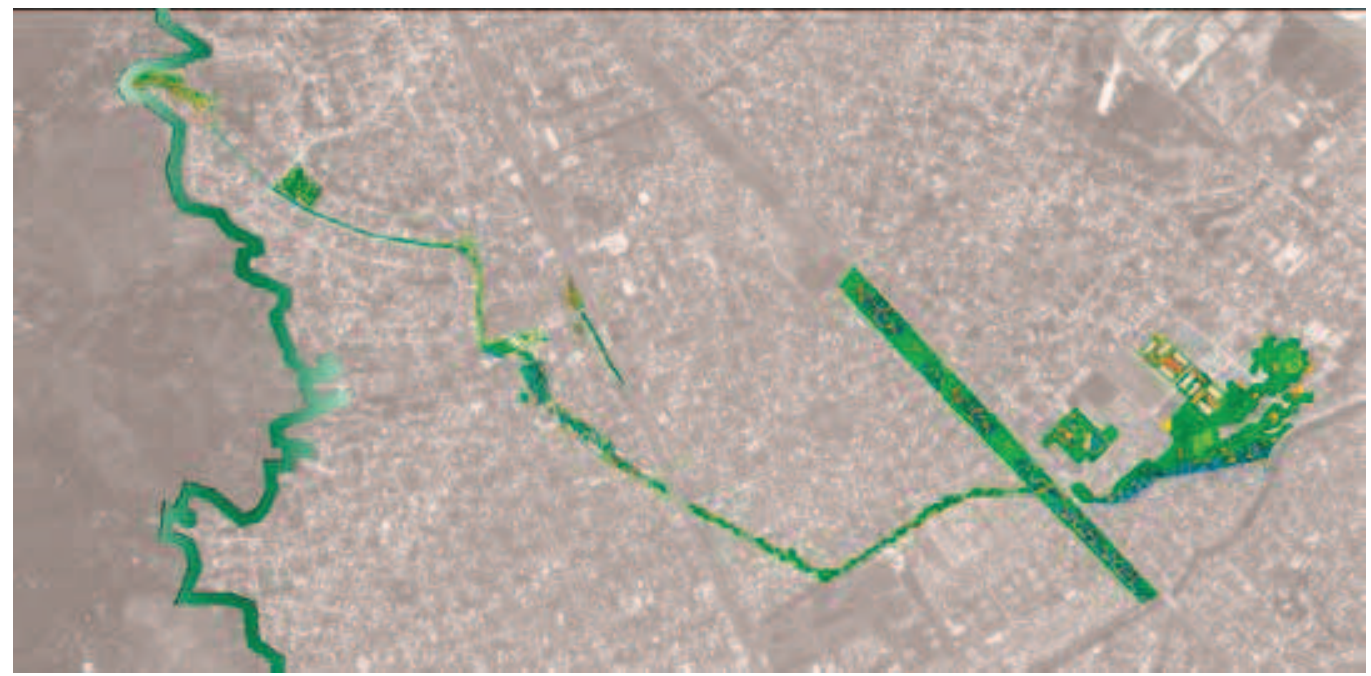

Figura 8 Plano geral do projeto paisagístico.

Fonte: Lourenço $(2013$, p. 126).

\section{Detalhamento do Projeto}

O projeto foi dividido por trechos, totalizando seis, de acordo com características urbanas e ambientais, conforme pode ser observado na figura 9, que mostra uma visão geral do projeto proposto a partir do ponto em que o rio Dona Eugênia entra na cidade, trechos I e II de intervenção, até a sua foz no rio Sarapuí, no trecho VI de intervenção. 


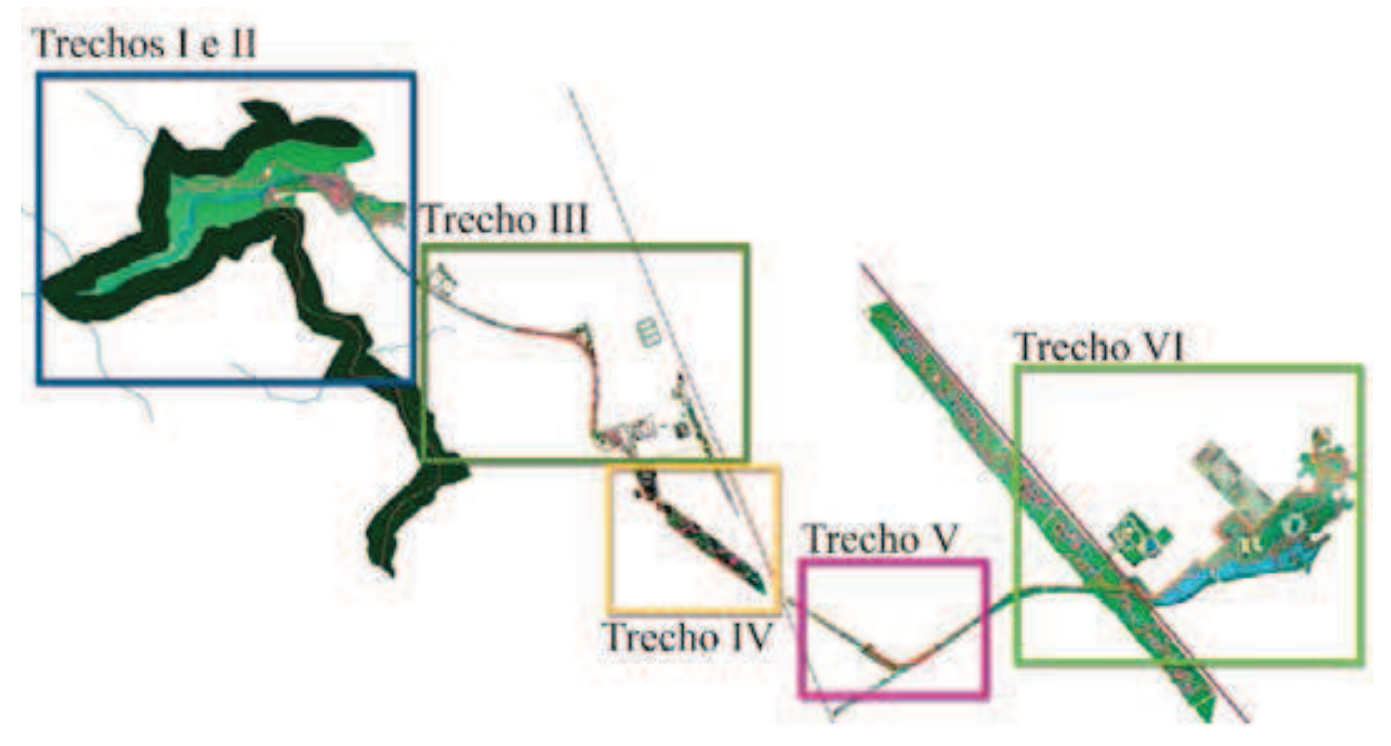

Figura 9 Plano Geral em Trechos. Fonte: Lourenço (2013, p. 140).

As figuras de 10 a 21 apresentam com mais detalhes as propostas de projeto ao longo dos trechos I a VI de intervenção no ambiente urbano e ambiental.

\section{Trecho I: Parque Urbano de Borda}

Tem como objetivos a prevenção da polvição dos corpos hídricos, a recuperação e manutenção das Áreas de Preservação Permanente (APPs), assegurando a proteção dos recursos naturais. Visa alcançar esses objetivos por intermédio da articulação e sensibilização da administração pública e da sociedade civil, para planejar, disciplinar e conter a expansão urbana sobre áreas de relevante biodiversidade, Unidades de Conservação (UCs), APPs e de solos férteis, promovendo a integração da gestão de recursos hídricos com a gestão de ecossistemas e assentamentos humanos. Por fim, corroborando com o uso racional dos recursos naturais, prevê-se a implementação de programa de incentivo ao aproveitamento da água de chuva e reuso de água potável.

Com base no diagnóstico realizado para o Trecho l, observou-se que o crescimento urbano desordenado e acelerado de comunidades carentes e de infraestrutura precária em direção à APA Gericinó/Mendanha compreende a principal questão envolvendo esse trecho, tanto em termos de planejamento e infraestrutura urbana, quanto em relação aos aspectos ambientais, pois já são presentes a degradação da vegetação e o risco à nascente do rio.

Para mitigar os problemas, prevenir o agravamento da situação diagnosticada, e/ou o surgimento de novas ameaças, e potencializar os atributos existentes, com as soluções propostas espera-se a preservação dos recursos naturais e o planejamento do crescimento urbano. Para tanto, como primeira ação tem-se a transformação da 
APA em reserva biológica. Essa medida visa à preservação integral da biota e demais atributos naturais existentes em seus limites, permitindo a realização de pesquisas e experimentações científicas com prévia autorização. Nas reservas biológicas é proibida a visitação pública, exceto com objetivo educacional. $\bigcirc$ parque urbano de borda será responsável por promover a aproximação e conscientização da população em relação aos recursos naturais por meio dos espaços destinados ao lazer e à contemplação. Prevê-se a exploração da área com plantio de espécies frutíferas, permitindo o desenvolvimento de atividade econômica - comum, historicamente, na região. Tais ações colaboram para despertar na população o respeito e cuidado necessários para a manutenção dos recursos existentes. Além disso, é fundamental delimitar a área para expansão urbana e promover a realocação de habitações para locais com infraestrutura adequada, com base no planejamento urbano mais consciente.

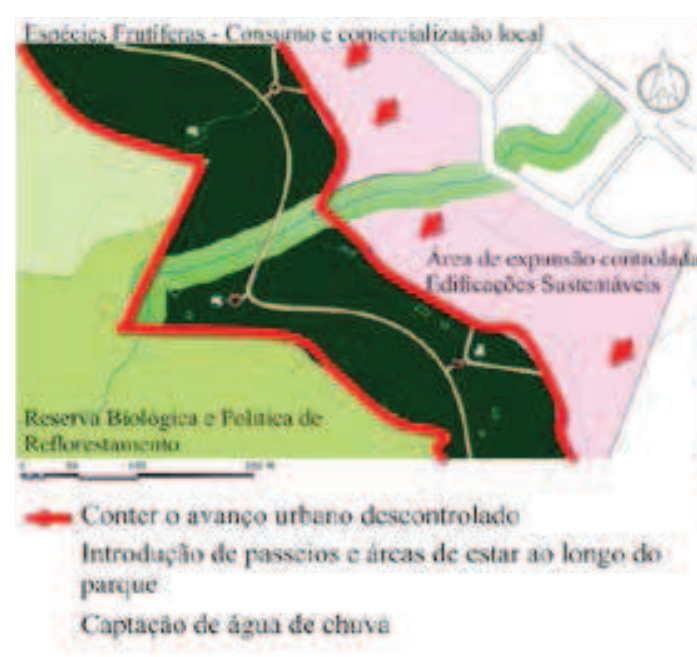

Figura 10 Prancha 1 - Trecho I do detalhamento do projeto. ${ }^{4}$ Fonte: Lourenço (2013, p. 141).

\section{Trecho II: Parque Urbano de Transição}

Tem como objetivo criar uma transição mais amena entre a área mais densamente urbanizada e o parque já existente - um braço do parque na cidade. Além disso, conecta-se com o parque de borda contra o avanço descontrolado da urbanização.

A degradação da vegetação e o risco à APA são as principais questões ambientais elencadas pelo diagnóstico do trecho II. Em termos de infraestrutura, observou-se ser uma área de caráter residencial, com grandes possibilidades de tornar-se mais uma comunidade de crescimento desordenado e com baixa qualidade de vida.

Infraestrutura verde: redes multifuncionais de fragmentos permeáveis e vegetados interconectados, que reestruturam o mosaico da paisagem. (HERZOG, 2009). 


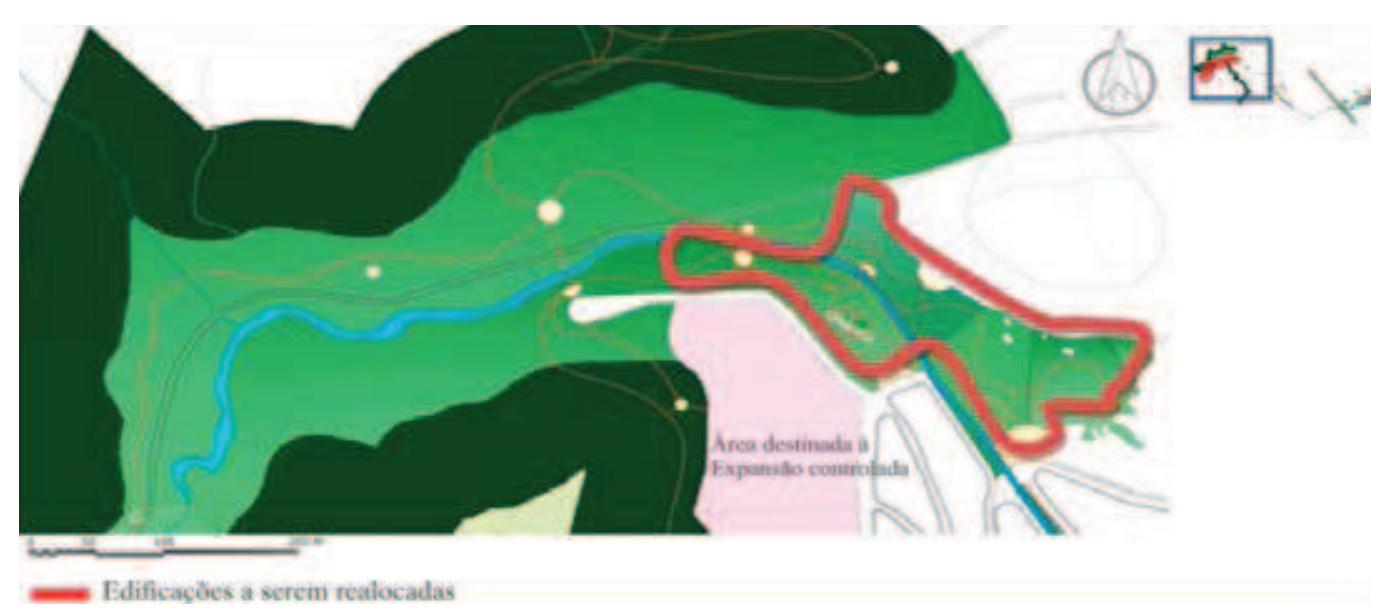

Figura 11 Prancha 2 - Trecho II do detalhamento do projeto. Fonte: Lourenço (2013, p. 142).

\section{Soluções Propostas}

Preservar os recursos naturais através da constituição de um parque urbano de transição, cujo objetivo é conectar a reserva biológica à área urbana, braço do parque em área urbana, é a principal solução proposta para o trecho. $O$ parque urbano de transição funcionará como um pulmão verde junto ao parque urbano de borda e a reserva biológica, conciliando a aproximação da população em relação aos recursos naturais por intermédio de espaços destinados ao lazer e à contemplação - passeios, áreas de estar, espaços recreativos e exploração econômica: quiosques e viveiros de plantas nativas. Além disso, estimula-se a exploração ecoturística com atividades ecológicas, como trilhas e arvorismo. Também são previstos reaproveitamento da água de chuva, pisos permeáveis e reconstituição da vegetação. Para tanto, propõem-se a realocação de habitações de áreas consideradas de risco, faixa marginal e cota elevadas, como meio de conter o crescimento acelerado e permitir o uso dessa área como aqui proposto.

\section{Trecho III: Espaços Livres Urbanos}

Este trecho é marcado por uma pequena concentração de áreas livres públicas em meio à massa urbana consolidada, como campo de futebol público e praças. A tais áreas foram incorporados corredores verdes e uma potencial área de detenção às margens da linha férrea (observou-se grande acúmulo de água em caso de cheia). Além do potencial de lazer e recreação, esses espaços possuem a função de amortecer as enchentes por intermédio de áreas que suportam o acúmulo de água durante as cheias urbanas - bacias de detenção.

O diagnóstico do trecho III reconhece uma área de ocupação urbana já consolidada, de caráter misto, residencial e comercial, com significativa densidade e algumas áreas 
livres públicas que podem ser incorporadas ao sistema de espaços livres. Aponta, em relação aos fatores ambientais, a degradação da vegetação, principalmente a marginal, e a polvição do rio como principais questões a serem solucionadas.

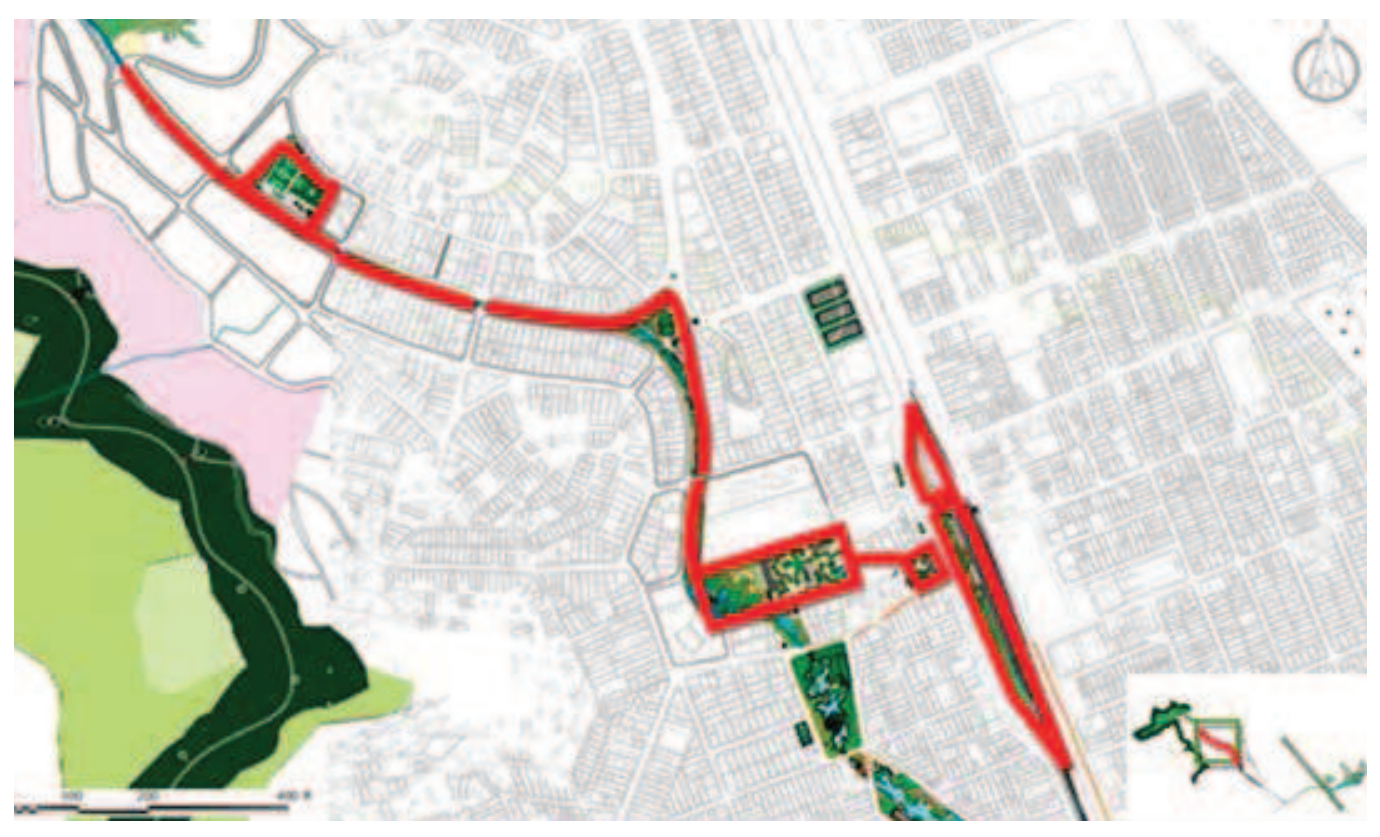

Figura 12 Prancha 3 - Trecho III do detalhamento do projeto. Fonte: Lourenço (2013, p. 122).

Como soluções propostas, apresenta-se a criação de espaços públicos com múltiplas funções, conectados por corredores verdes, potencializados pela melhoria da mobilidade urbana por meio do tratamento marginal, com implantação de passeios, ciclovia e remodelação das vias marginais - passando à mão única, em traffic calming.

Os corredores verdes conectam as áreas livres existentes nesse trecho e estas ao parque urbano de transição, utilizando-se de vegetação ripária para as margens e vegetação esteticamente atrativa para a zona urbanizada.

Quando em época de seca, os espaços públicos com múltiplas funções, praças e campos, são utilizados para lazer, contemplação, prática esportiva e meio de exploração econômica, aproximando a população do rio (acessibilidade às suas margens). Quando em época de cheia do rio, assumem função de bacia de detenção, iá que foram reconhecidos como indispensáveis ao sistema de micro e macrodrenagem. Dessa forma, novas tipologias para praças e campos foram utilizadas, promovendo a possibilidade de abertura do leito do rio em alguns casos.

Propõe-se, ainda, a utilização de recursos da infraestrutura verde, pisos permeáveis e jardins de chuva, colaborando para o melhor funcionamento da microdrenagem. Por fim, para amenização da ruptura criada pela linha férrea, propõe-se a substituição do muro por gradil. Dessa forma, é possível, pelo menos, reestabelecer a conexão visual entre as margens da linha férrea. 


\section{Trecho III: Espaços Livres Urbanos - Detalhes}

\section{Campo de Futebol}

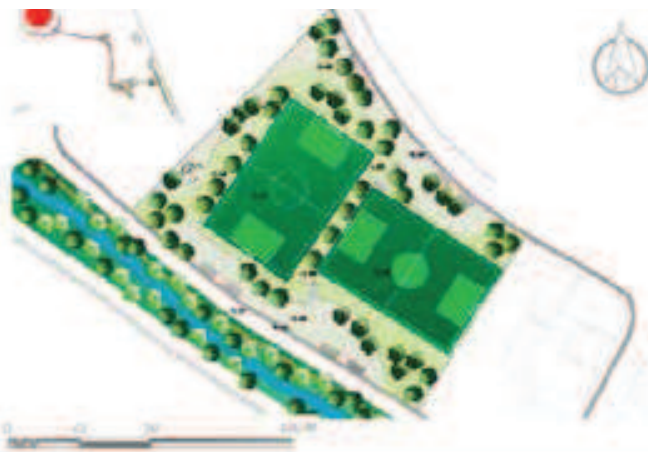

Os campos de fitebel șe utilizades tante pura recreaçlo e lazer da populaçâs, quanto para drenagem urbana enquanto baeia de detenç̧o em periodos de cheia.

Bacia de Detençào - as cotas variam de $-0.40 \mathrm{~m}$ a - 1.15 .

Alèm disso, a espaço foi valorizade com melhor infraestrutura: bances, arhorizacâo, espacos de ginastica. acessibilidade, permeabihilade do soloe quiesques.

Existe a interaça facilitada do espaçe com a faisa marginal. jä que toda a via marymalé trabathada com rraffic colming, o que permite o acesse tanto à rede cicloviuria. quante aos pasecios marginais.

Figura 13 Prancha 4 - Trecho III do detalhamento do projeto.

Fonte: Lourenço $(2013$, p. 122).

\section{Praça Brasil}

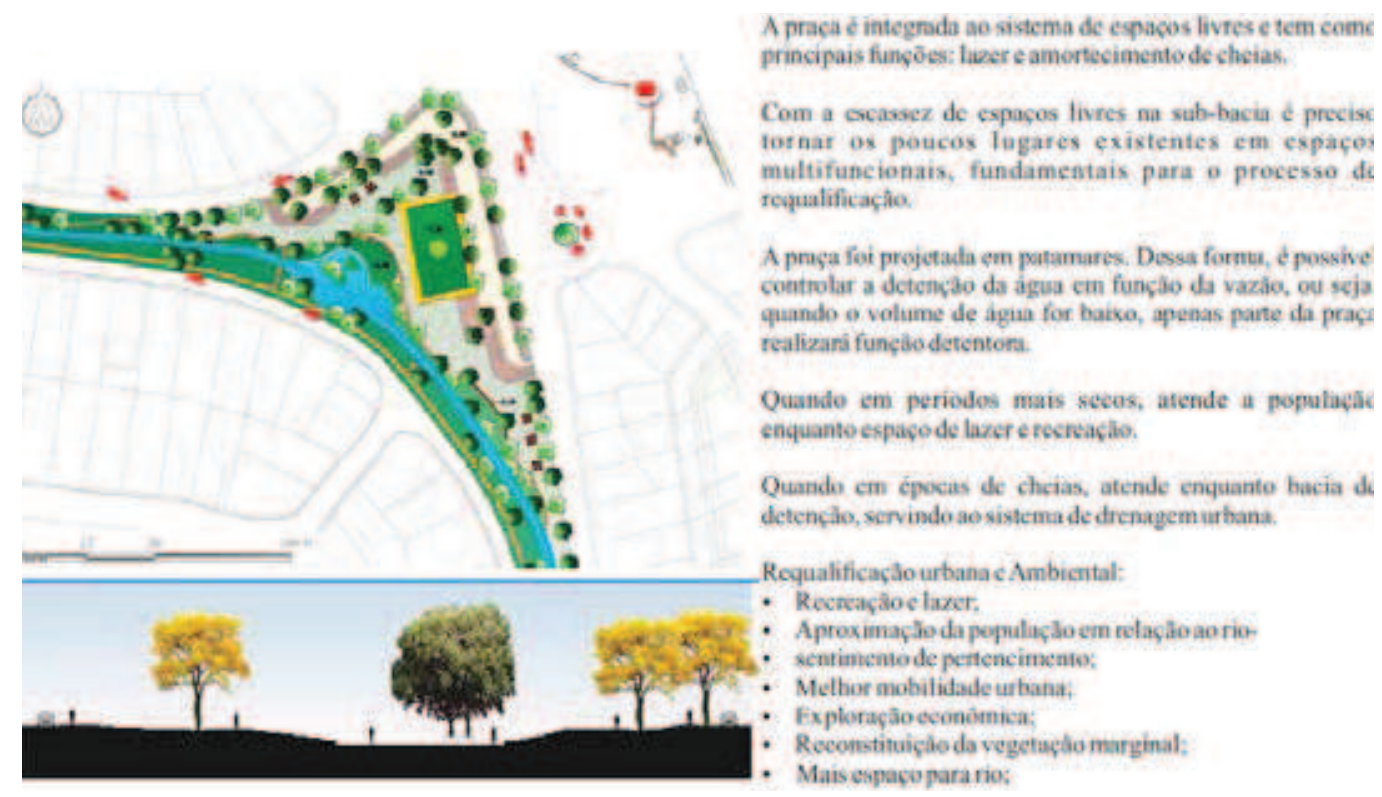

Figura 14 Prancha 5 - Trecho III do detalhamento do projeto. Fonte: Lourenço (2013, p. 145). 


\section{Praça da Prefeitura}

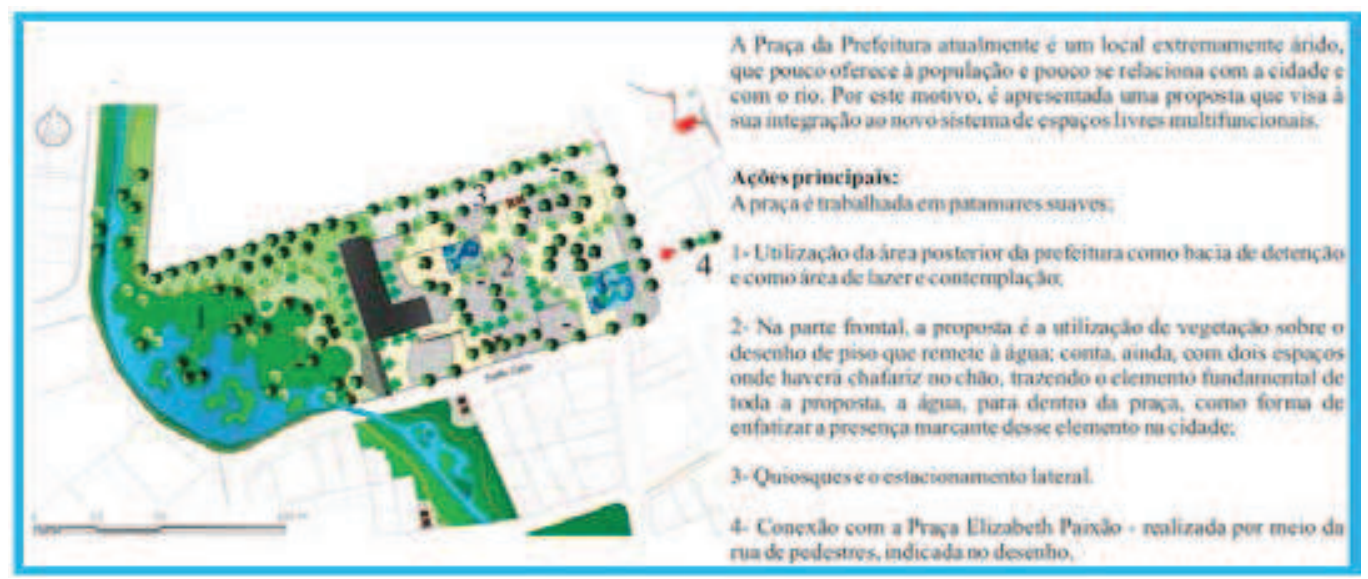

Figura 15 Prancha 6 - Trecho III do detalhamento do projeto Fonte: Lourenço (2013, p. 148).

\section{Corredores Verdes}

\section{Principais fuņeles:}

Requalificaçâo Marginal:

- Reconstituiçào da fuena e fleca:

- Retirada da canalizacto concretadas

- Recutrofuraçáo vairia

- Promocalo de apeoximaçes subjetivas - ciclowias e passeios,

\section{Cenecter:}

Conectar es diferentes treches do projeto.

Amertecimente de cheias

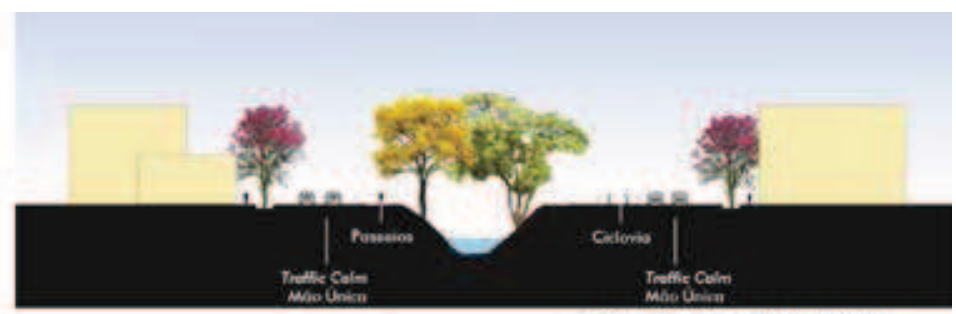

Tipolegias de Infraestrufura
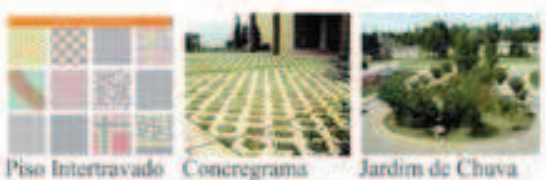

- Uhilizaclo de pisos permeriveis em passeios, ciclovia e Thaffic calm:

- Jardim de Chuva - canteiros de arborizacào urhanas:

Figura 16 Prancha 7 - Trecho III do detalhamento do projeto $^{5}$. Fonte: Lourenço (2013, p. 144).

\section{Trecho IV: Área Marginal Crítica}

Este trecho pode ser considerado crítico em relação à ocupação irregular das margens do rio e à ausência de espaços livres. Outro ponto importante é a dificuldade de transposição da linha férrea. $O$ que acontece atualmente é o extremo estreitamento da calha do rio e a total segregação do espaço.

Jardim de Chuva - depressão pouco profunda na terra em um terreno com solo permeável, com plantas ou árvores e coberto por um sistema natural de drenagem. Absorve a água da chuva acumulada em superfícies impermeáveis, como calçadas e ruas, permitindo infiltração na terra, em vez de jogá-la para redes de drenagem ou canais. 


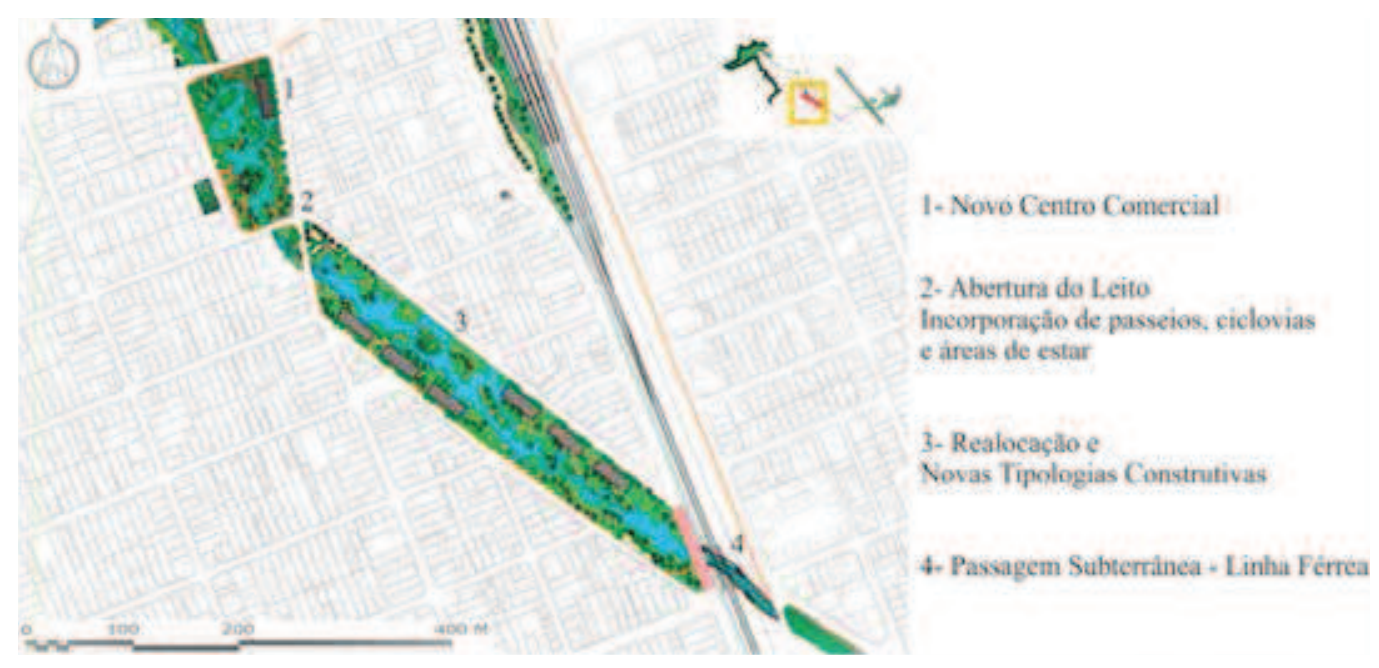

Figura 17 Prancha 8 - Trecho IV do detalhamento do projeto. Fonte: Lourenço (2013, p. 151).
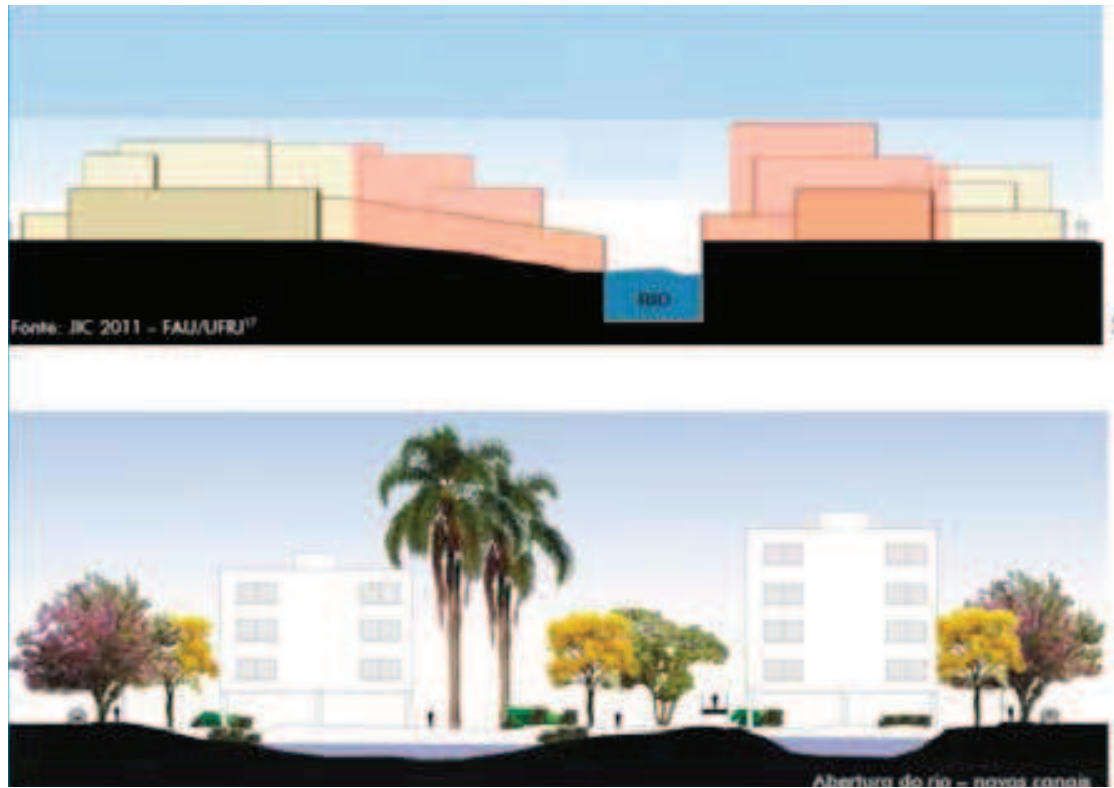

Situaçăo Alternativı

Figura 18 Prancha 9 - Trecho IV do detalhamento do projeto.

Fonte: Imagem da situação Atual: JIC - "Revitalização do rio Dona Eugênia" - 2011 , FAU/UFERJ. Isabella Adauto Costa, Mariana Bressan e Vinicius Furtado. Orientação: Ana Lúcia Britto, Eliane Bessa e Paulo Roberto Carneiro. Fonte da situação alternativa: Lourenço (2013, p. 122).

Neste trecho, o diagnóstico aponta a situação mais crítica, tanto em aspectos ambientais, quanto urbanos. A área apresenta forte caráter misto, residencial e comercial com alta densidade. As edificações, em sua maioria, estão nas margens do rio, formando uma barreira e estreitando sua calha. $O$ rio fica totalmente escondido atrás das edificações e torna-se apenas receptáculo de lixo e esgoto. 
As soluções propostas estão alicerçadas na realocação das edificações em área marginal, porém novas edificações serão propostas para o mesmo lugar, sob nova tipologia construtiva. Não necessariamente os moradores serão realocados para essas novas edificações, podendo-se optar por áreas previstas para expansão urbana, onde terão assegurada a possibilidade de manter o padrão tipológico "casa", comum na região. A tipologia escolhida para este trecho é a construção sobre pilotis, pois permite abertura do leito, facilita o fluxo das águas, vegetação e animais, assegurando continuidade sistêmica.

Associada às soluções apresentadas, não se pode ignorar a mobilidade urbana. Nesse caso, mantém-se o padrão do projeto, com a promoção de passeios e ciclovias, formando uma rede por toda extensão do corpo hídrico.

Outro fator importante neste trecho é a segregação promovida pela linha férrea. Como solução, aponta-se a abertura do leito do rio e implantação de passagem subterrânea, conectando as duas margens da linha férrea. Além disso, opta-se pela substituição do muro por gradil - reabilitando o contato visual entre margens da ferrovia. Por fim, sugere-se a implantação de jardins de chuva paralelos ao gradil como forma de colaborar para a amenização da situação crítica da microdrenagem.

\section{Trecho V: Rio sob Novo Ângulo}

Este trecho do rio apresenta-se como área de caráter residencial, com faixas marginais ainda vegetadas e o rio não canalizado, pontos positivos e facilitadores da conexão entre os trechos.

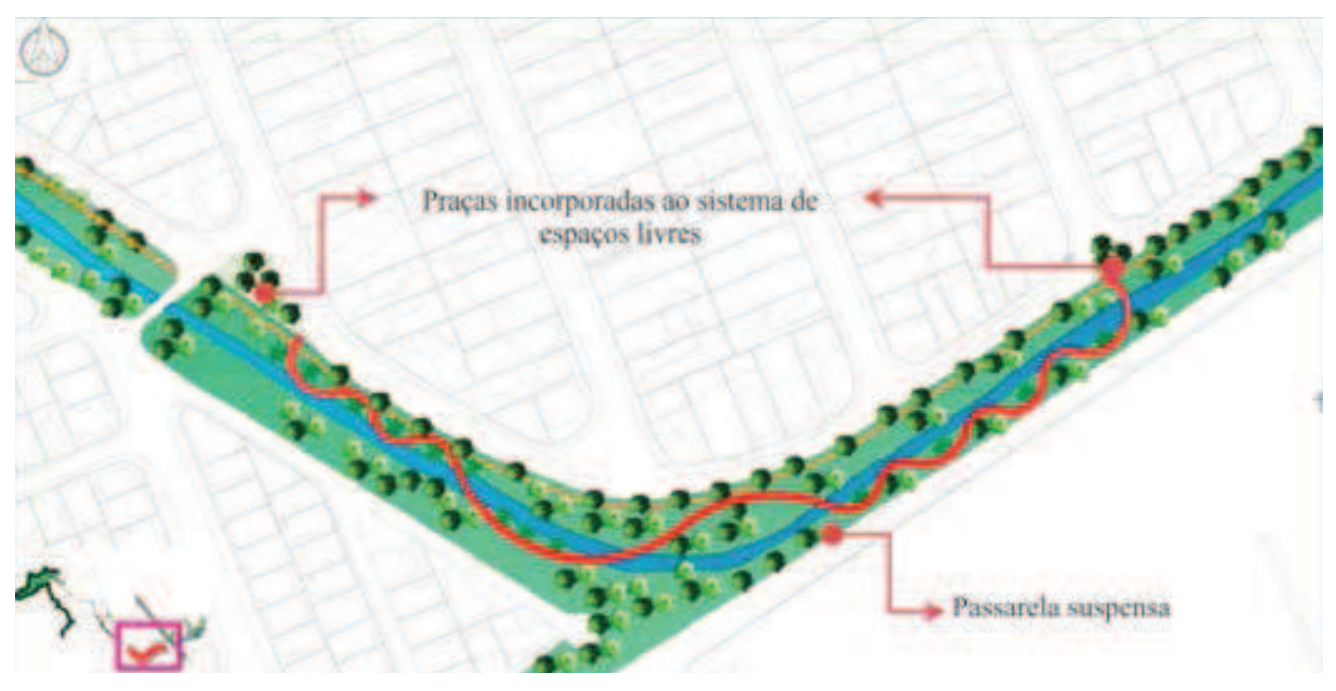

Figura 19 Prancha 10 - Trecho $\mathrm{V}$ do detalhamento do projeto. Fonte: Lourenço (2013, p. 156).

Como solução proposta preveem-se a fomentação da vegetação já existente, a continuidade de passeios e ciclovias e a incorporação das pequenas praças à margem do rio. O projeto conta com a implantação de uma passarela suspensa, possibilitando 
à população a observação do rio sob novo ângulo, tirando o observador do chão. Por fim, este trecho conecta-se ao trecho final do projeto, o parque urbano de Zona Úmida.

\section{Trecho VI: Parque Urbano de Zona Úmida}

O parque foi proposto em função das características naturais de área e com intuito de protegê-las.

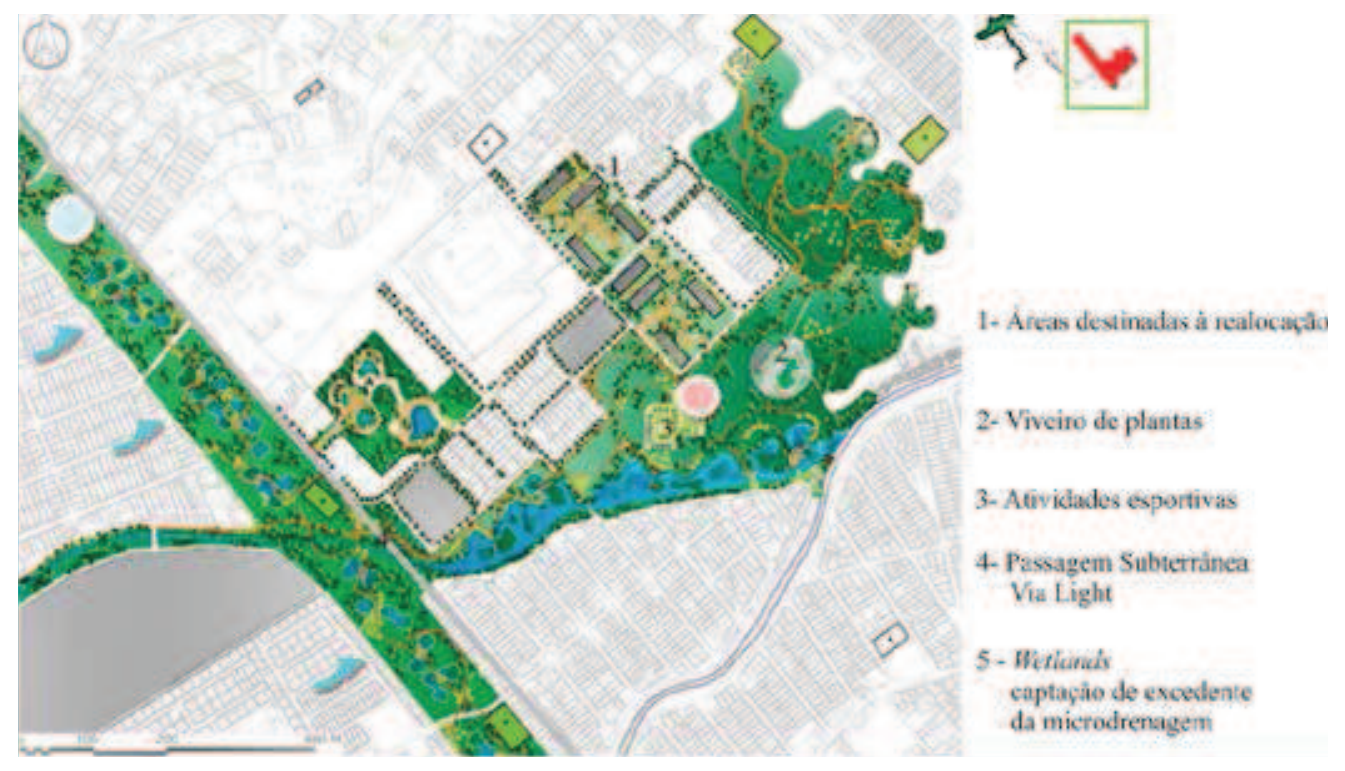

Figura 20 Prancha 11 - Trecho VI do detalhamento do projeto. Fonte: Lourenço $(2013$, p. 157).

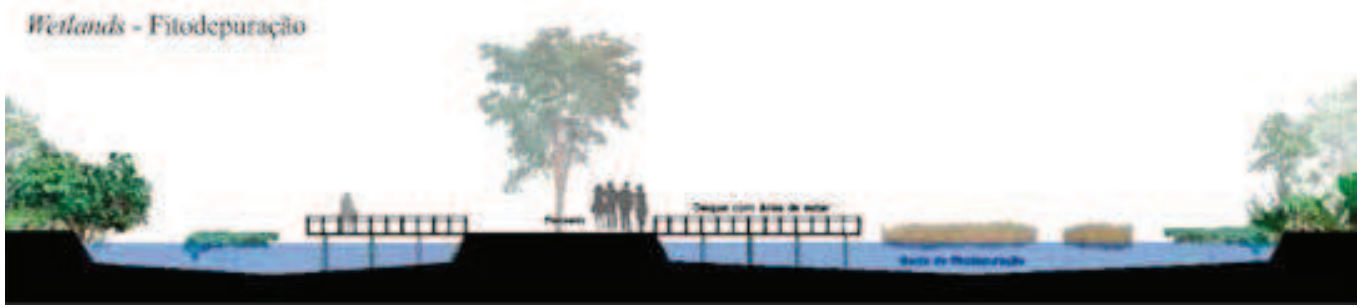

Figura 21 Corte Wetlands - Trecho VI do detalhamento do projeto. Fonte: Lourenço $(2013$, p. 158).

O diagnóstico identifica o último trecho do projeto como a foz do rio Dona Eugênia, uma zona úmida, ou seja, uma área frágil, que deve ser preservada - porém essa área é considerada de expansão urbana e já apresenta crescimento urbano desordenado, com comunidades carentes nas áreas alagáveis e faixas marginais.

Propõe-se a implantação de um parque urbano de zona úmida para a preservação dessa área, fundamental ao ciclo natural das águas, berçário de espécies da fauna e flora. Esse parque será conectado a uma área de fitodepuração - prevista aqui para faixa não edificante da Via Light. Esses espaços contam com passeios sobre deques, 
preservando o fluxo das águas, implantação de viveiros de plantas, incentivando atividades econômicas, e implantação de áreas esportivas. Para tanto, promove-se a realocação das habitações de área de risco e prevê-se a expansão controlada, com tipologias pré-determinadas.

\section{DISCUSSÕES FINAIS}

O presente trabalho procurou demonstrar a importância do projeto paisagístico para o processo de requalificação de um rio, buscando recuperar seus aspectos ambientais e reestruturar as condições urbanas que o envolvem por meio do estudo de conceitos, referenciais e sua aplicação para a concepção de possíveis diretrizes e soluções projetuais para um rio urbano. Procurou, também, integrar elementos do paisagismo, do urbanismo e da engenharia.

As medidas propostas apontam, segundo as manchas de alagamento, resultados que eliminam vários pontos de alagamento e diminuem a lâmina d'água em outros, parecendo capazes de potencializar aspectos positivos da sub-bacia e mitigar os negativos, tendo impacto direto na qualidade de vida da população e na melhoria do ambiente natural.

O trabalho foi desenvolvido como grande oportunidade para discussão da requalificação de rios em áreas urbanas, mostrando o quanto são importantes o reconhecimento e a adoção de novos modelos de intervenção, nos quais a água e os recursos naturais sejam tomados como elementos essenciais, diferente das políticas não integradoras adotadas atualmente, que tomam o ambiente urbano como separado do ambiente natural. Houve oportunidade de discutir a necessidade de reconhecer que a urbanização deve coexistir com o meio natural, ou seja, jamais deve haver a supressão de um em favor do outro.

A proposta visou colaborar para o desenvolvimento urbano sustentável por meio de um modelo de intervenção capaz de abranger aspectos ambientais, econômicos e sociais.

As paisagens multifuncionais, concebidas no sistema de espaços livres, foram a base para a requalificação da paisagem. Tais paisagens permitem o diferente uso dos espaços em diferentes condições, por isso foram fundamentais para a requalificação que busca a mitigação de carências ambientais, sociais e de infraestrutura urbana.

Pode-se enfatizar que este trabalho não se encerra aqui, sendo possível a continuidade do processo interdisciplinar, buscando adequações projetuais necessárias para constituição do cenário ideal, atendendo a carências de infraestrutura e sociais, integrando a cidade e o rio (ambiente natural), chegando ao objetivo de desenvolver soluções sustentáveis. 


\section{REFERÊNCIAS BIBLIOGRÁFICAS}

BRANDÃO, Ana Maria de P. M. Clima urbano e enchentes na cidade do Rio de Janeiro. In: Guerra, A. J. T.; Cunha, Sandra B (Orgs.). Impactos ambientais urbanos no Brasil. Rio de Janeiro: Bertrand Brasil, 2004, p. 47-109.

CENTRO ITALIANO PER LA RIQUALIFICAZIONE FLUVIALE (CIRF). La riqualificazione fluviale in Italia: linee guida, strumenti ed esperienze per gestire i corsi d'a cqua e il territorio. Nardini A. \& Sansoni G., editores. Venezia: Mazzanti, 2006. 832 p.

CORMIER Nathaniel S.; PELLEGRINO, Paulo Renato Mesquita. Infraestrutura verde: uma estratégia paisagística para a água urbana. Paisagem e Ambiente: ensaios. São Paulo: FAUUSP, n. 25, 2008, p. 125-1 42.

COSTA, Lucia M. S. A. Rios e paisagens urbanas em cidades brasileiras. Rio de Janeiro: Viana \& Mosley, Prourb, 2006, p. 9-15.

FABOS, Julius. G. Land-use planning: from global to local challenge. New York: Dowden and Culver, 1985. 223 p.

HERZOG, C. P. Guaratiba verde: subsídios para o projeto de infraestrutura verde em área de expansão urbana na cidade do Rio de Janeiro. 2009. 189 f. Dissertação (Mestrado em Urbanismo) - Faculdade de Arquitetura e Urbanismo da Universidade Federal do Rio de Janeiro, Rio de Janeiro, 2009.

INSTITUTO BRASILEIRO DE GEOGRAFIA E ESTATÍSTICA (IBGE), 2010. Disponível em: <http://cidades.ibge.gov.br/ xtras/perfil.php?codmun=330285>. Acesso em: 6 mai. 2015.

JOHNSON, Bart R.; HILL, Kristina (Orgs.). Ecology and design: frameworks for learning. Washington: Island Press, 2002.

LAURIE, Michael. An introduction to landscape architecture. New York: American Elsevier Company. Inc, 1975. $91 \mathrm{p}$.

LOURENÇO, lanic Bigate. 2013. 184 f. Rios urbanos e paisagens multifuncionais: o projeto paisagístico como instrumento de requalificação urbana e ambiental. 2013. Dissertação (Mestrado em Arquitetura Paisagística) Universidade Federal do Rio de Janeiro, Rio de Janeiro, 2013.

LYNCH, Kevin. Good city form. Cambridge, Massachusetts: The MIT Press, 1984. 524 p.

MANN, R. Rivers in the city. Nova York, Washington: Praeger Publishers, 1973, p. 13.

MARICATO, Ermínia. As ideias fora do lugar e o lugar fora das ideias - planejamento urbano no Brasil. In: ARANTES, O.; VAINER, C.; MARICATO, E (Orgs.). A cidade do pensamento único: desmanchando consensos. Petrópolis: Vozes, 2000, p. 121-192.

McHARG, lan L. Design with nature. New York: Natural History Press, 1969. 208 p.

MIGUEZ, M. G.; MASCARENHAS, F. C. B.; MAGALHÃES, L. P. C. Multifunctional landscapes for urban flood control in developing countries. International Journal of Sustainable Development and Planning, vol. 2, $\mathrm{n}^{\circ} 2,2007$, p. $153-528$

NASSAUER, Joan. Cultural sustainability: aligning aesthetics and ecology. In: NASSAUER, Joan (Org.). Placing nature. Washington: Island Press, 1997, p. 64-83.

NEWMAN, Peter; JENNINGS, Isabella. Cities as sustainable ecosystems: principles and practice. Washington: Island Press, 2008. 296 p.

PLANO DIRETOR DE RECURSOS HÍDRICOS DA REGIÃO HIDROGRÁFICA DA BAÍA DE GUANABARA. Rio de Janeiro: Governo do Estado do Rio de Janeiro. Programa de Despoluição da Baía de Guanabara. Projetos Ambientais Complementares. Consórcio Ecologus-Agrar, 2005.

PELLEGRINO, Paulo R. M. et al. A paisagem da borda: uma estratégia para a condução das águas, da biodiversidade e das pessoas. In: COSTA, Lucia S. A (Org.). Rios e paisagens urbanas em cidades brasileiras. Rio de Janeiro: Vianna e Mosley/PROURB, 2006, p. 57-76.

PREFEITURA MUNICIPAL DE MESQUITA: www.mesquita.ri.gov.br/

SCHLEE, Mônica Bahia; COELHO NETTO, Ana L.; TÂNGARI, Vera. Mapeamento ambiental e paisagístico de bacias hidrográficas urbanas: estudo de caso do rio Carioca. In: COSTA, Lucia M. S. A (Org.). Rios e paisagens urbanas em cidades brasileiras. Rio de Janeiro: Vianna e Mosley, 2006, p. 33-35.

SPIRN, Anne Whiston. O jardim de granito. São Paulo: Edusp, 1995. 360 p.

The authority of nature: conflict, confusion, and renewal in design, planning and ecology. In: JOHNSON, B. $\overline{R . ; ~ H I L L ~ K . ~ E c o l o g y ~ a n d ~ d e s i g n: ~ f r a m e w o r k s ~ f o r ~ l e a r n i n g . ~ W a s h i n g t o n, ~ D C: ~ I s l a n d ~ P r e s s, ~ 2002, ~ p . ~ 29-49 . ~}$ 
STEINER, Frederick R. Landscape planning: a method applied to a growth management example. Environmental Management 15 (4), 1991, p. 519-529.

VERÓL, Aline Pires. Requalificação fluvial integrada ao manejo de águas urbanas para cidades mais resilientes. 2013. 345 f. Tese (Doutorado em Engenharia Civil) - Instituto Alberto Luiz Coimbra de Pós-Graduação e Pesquisa de Engenharia, Universidade Federal do Rio de Janeiro, Rio de Janeiro, 2013.

\section{AGRADECIMENTOS}

Os autores agradecem a Coordenação de Aperfeiçoamento de Pessoal de Nível Superior (Capes), o Conselho Nacional de Desenvolvimento Científico e Tecnológico (CNPq) e a Financiadora de Estudos e Projetos (Finep) pelas bolsas e apoio concedidos para o desenvolvimento desta pesquisa.

Nota do editor

Submissão: 30 jun. 2015

Aprovação: 31 ago. 2015 